\title{
An economic study for the use of Solar energy in the irrigation of reclaimed agricultural lands inAssiut Governorate
}

\section{Ehab Moreed Sharabin}

\section{Address:}

Agricultural Economics Research Institute, Agricultural Research Center, Giza, Egypt

Corresponding author: Ehab M. Sharabin,dr.ehab19712012@yahoo.com

Received:01-09-2021; Accepted: 23-11-2021; Published: 27-11-2021

\section{ABSTRACT}

The cost of energy sources used for irrigation in reclaimed land in Assiut Governorate is a growing problem due to the high prices of electricity and diesel used for irrigation. Therefore, this research aims to study the daily needs of water crops, based on which the solar power plant operating under various irrigation systems is proposed as an alternative source of electricity, and study also comparison among irrigation methods for the three categories of possession (less than 10 acres, larger than 10 acres and less than 20 acres, larger than 20 acres) is under study and the differences between the irrigation costs due to the use of various energy methods and both direct solar energy and hybrid energy in the reclaimed agricultural lands in the most important provinces of Assiut Governorate.Finally; study and compare the advantages and disadvantages of solar, electricity and diesel water pumps. The solar pumping program was used according to the water need for crops, and a serious study was conducted to compare the uses of various energy sources to irrigate reclaimed agricultural land. From the study of the feasibility study of the project during the 25 years of its establishment in which the most important results were that the use of direct solar energy and hybrids on the one hand and electricity on the other to obtain energy for spray irrigation for the selected zones for the different categories of possession at which Albadari zone has the largest decrease where it is estimated at about $99.17 \%$, $74.42 \%$ for the third category of possession of electricity, respectively, andAlfathzone was the lowest, with an estimated $19.92 \%, 10.68 \%$ for the firstpossession class of direct solar electricity and hybrids, respectively. In the case of drip irrigation, Albadarizone also recorded the largest reduction of the difference between direct solar energy, hybrid and electricity, estimated at $99.9 \%$, $72.09 \%$ of electricity for the third category.Manflotzone recorded a lower rate of $16.81 \%, 5.7 \%$ of electricity, either direct or hybrid, respectively, during the study period. Therefore, the study recommends the work of a solar power plant, due to the existence of avariance between the systems of energy use in irrigating the reclaimed agricultural lands, as the irrigation costs per acre were reduced in all centers instead of the use of electricity.

Keywords: Solar energy, hybrid solar energy, Feasibility, Two-way analysis of variance. 


\section{دراسة اقتصادية لاستخدام الطاقة الثمسية فى رى الإراضى الزراعية المستصلحة بمحافظة أسيوط

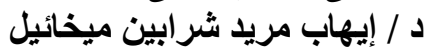 \\ معهد بحوث الاقتصاد الزر اعى ـ مركز البحوث مريد الزين ميخئيل الزر اعية ـ الجيزة ـ مصر}

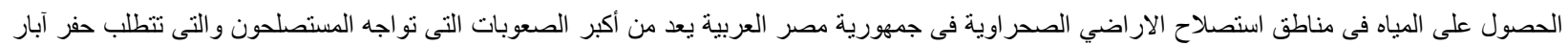

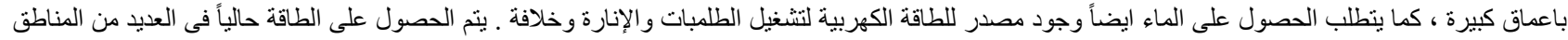

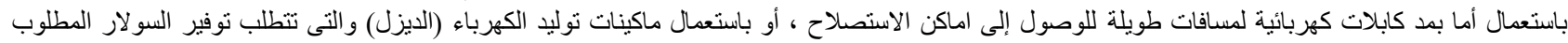

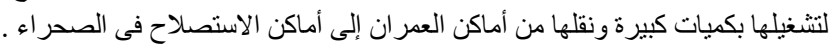

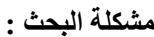

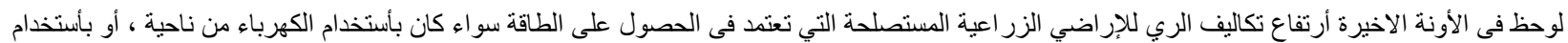

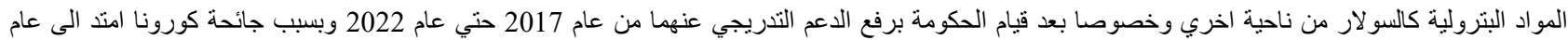

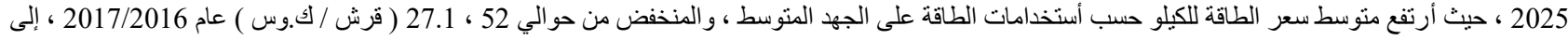

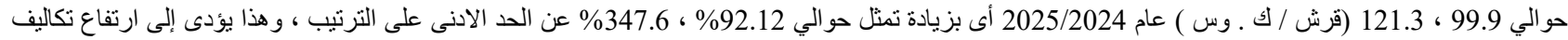

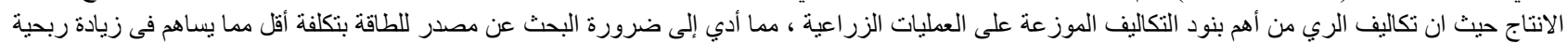

يستهدف البحث الوقوف على أستخدام الطاقة الثمسية للحصول على الطاقة فى ري الإر اضي المستصلحة المزرو عة بمحافظة أسيوط على الاهداف التالية :-

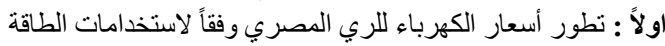

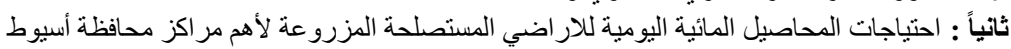

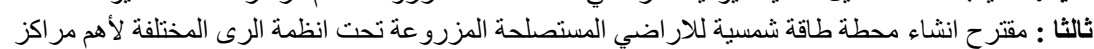
محافظة أسيوط النياء

رابعاً: دراسة فروق تكاليف الرى بأستخدام مصادر الطاقة الرختلفة بأهم مركز محافظة أسيوط

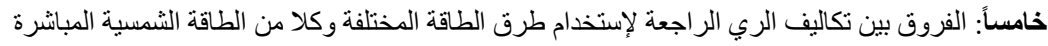

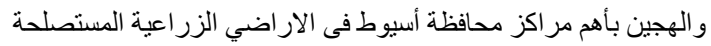
سادساً : أهم المؤشر بات الاقتصادية لبيان أهمية أستخدام الطاقة الثمسية على مستوى فئات العينة لمر اكز

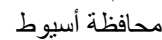

سابعاً: در اسة المميز ات و العيوب لاستخدام مضخات المباة التي تعمل بالطاقة الثمسية و الكهرباء و الديزل

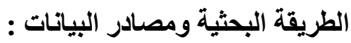

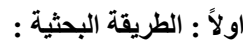

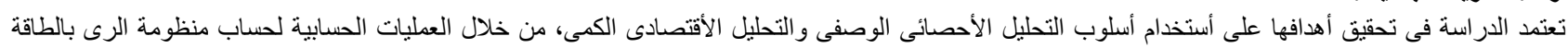

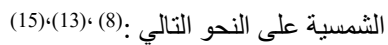

حسابات منظومة ضخ النخ المياه بالطاقة الثمسية :

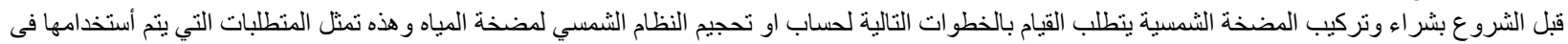

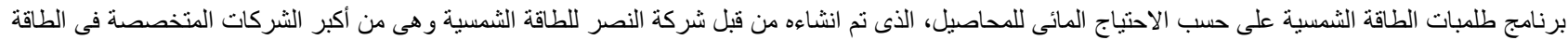

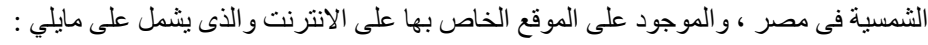

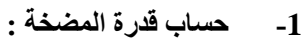

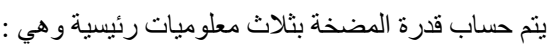

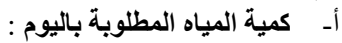
تحسب على اساس الاستعمال اليومي (لتر /يوم) او (م3/يوم) ويجب الأخذ فى الاعتبار عند حساب كمية الماء المتدفقة من الابار الجوفية وكذلك عند الحفر على العوامل التالية :

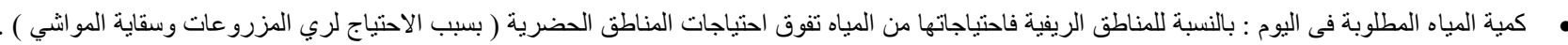

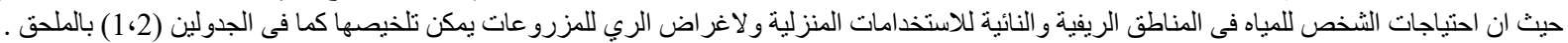

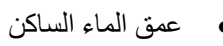

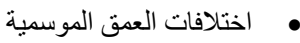

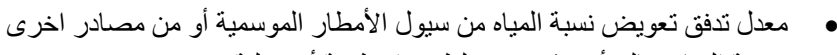

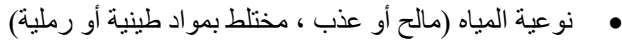
يحسب معدل تدفق المياه من المعادلة التالية

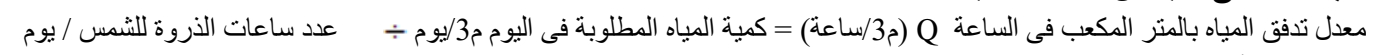

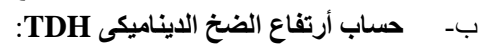
يشمل أرتفاع البئر مع المسافة العمودية حتى سطح الخزان الفان و العمق الاضافي الناتج من فو اقد الاحتكاك

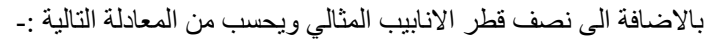
= Total Dynamic Head (m) Pumping Level $(A)+$ Vertical Rise (B) + Friction Loss $(C)$

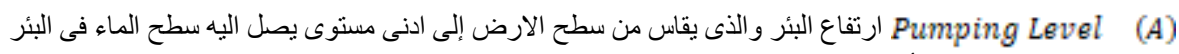

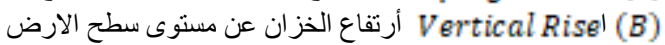
Friction Loss (C)

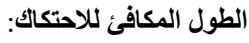




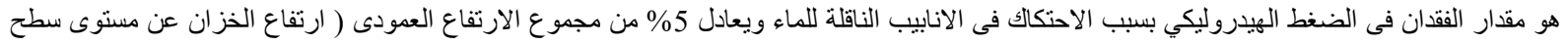

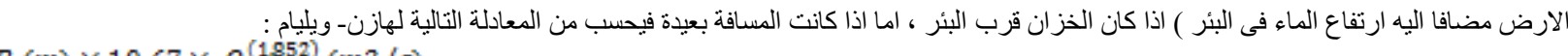
$\underline{B}(\mathrm{~m}) \times 10.67 \times Q^{[1852)}(\mathrm{m3} / \mathrm{s})$ $140^{(1.952)} \times d^{(4.9704)}(m)$

ولغرض حساب الفقدان فى الاحتكاك بين جريان الماء و الانبوب يتطلب حساب (d) قطر الانبوب الملائم لضخ المياه النئ وتقاس بوحدة البوصة (inch)

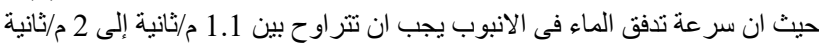

ج- قدرة وكفاءة المضخة : منئ

تحسب قدرة المضخة من المعادلة التالية :

$=$

pumping power (p pump) $=$

Flow rate $\left(Q\left(\frac{m^{2}}{s}\right)\right) \times T D H \times 0.002725$

pump Efficincy (ypump)\%

: : $Q\left(\frac{m^{3}}{g}\right)$

: ارتفاع الضخ الديناميكى : TDH

كاءة المضخة : pump Efficiency

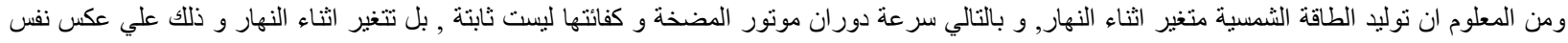

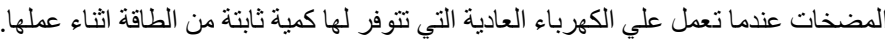

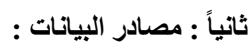

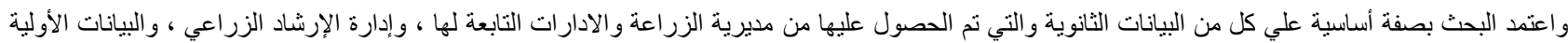

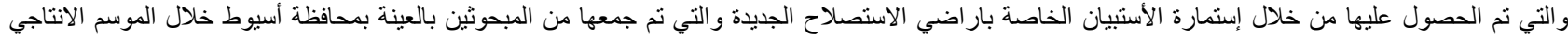

.2020/2019

وصف العينة :

تعتمد الدر اسة في الحصول علي البيانات الأولية لتحقيق أهدافها علي أستمارة الإستبيان و التي صمدت خصيصًا لهذا الغرض ،حيث تم سحب عينـة عشـوائية طبقيـة

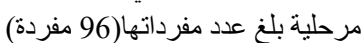

$N=\left(\frac{\sigma \mathrm{z}}{d}\right)^{2}$

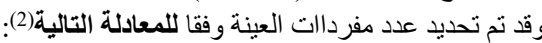

$$
\text { \%5 الانحر اف المعياري عند مستوير }
$$

حيث أن : : d خطأ التقدير

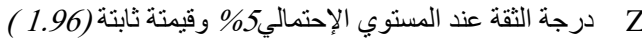

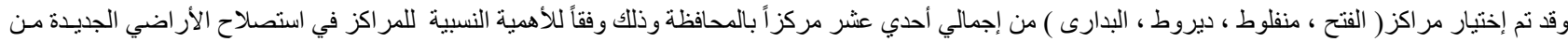

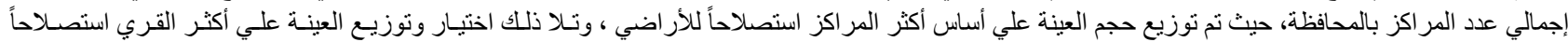

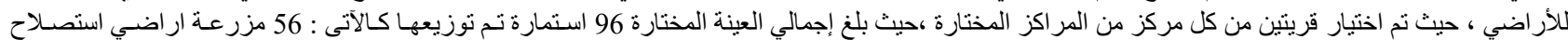

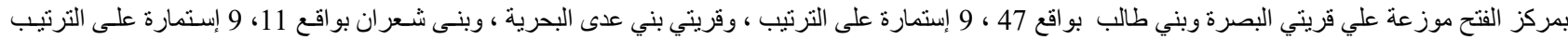

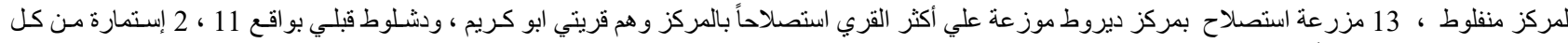

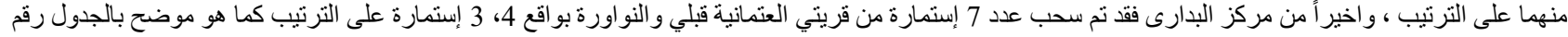

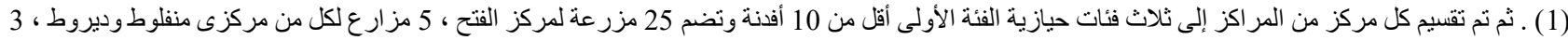

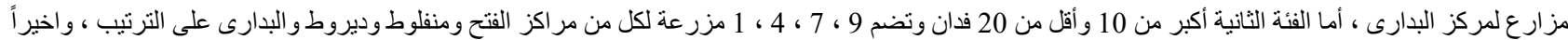

جدول رقم (1): اختيار عينة الاراسة بنواحى مراكز أسيوط للأراضي المستصلحة المزروعة بمحافظة أسيوط عام 2020 ـ

\begin{tabular}{|c|c|c|c|c|c|c|c|c|}
\hline الاستثمار ات & المشاهدات & اللهنتوسطى & المزار عيند & المزارعين & \% المستصلحة & 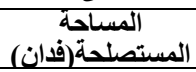 & الناحية & المركز \\
\hline 47 & 46.6 & 44.8 & 33.2 & 643 & 60.4 & 12442 & بصرة & \multirow{2}{*}{ الفتح } \\
\hline 9 & 8.7 & 8.4 & 17.6 & 341 & 4.0 & 822 & بنى طالب & \\
\hline 11 & 11.2 & 10.8 & 11.6 & 225 & 10.0 & 2066 & بنى عدى البحرية & \multirow{2}{*}{ منفلوط } \\
\hline 9 & 9.2 & 8.9 & 11.1 & 214 & 7.1 & 1469 & بنى شعران & \\
\hline 11 & 11.4 & 10.9 & 10.1 & 195 & 11.8 & 2440 & آبو كريح & \multirow[b]{2}{*}{ ديروط } \\
\hline 2 & 2.4 & 2.3 & 1.9 & 36 & 2.9 & 597 & دشلوط قبلى & \\
\hline 4 & 4.2 & 4.0 & 8.1 & 157 & 2.0 & 410 & العتمانية قبلح & \multirow{2}{*}{ البدارى } \\
\hline 3 & 3.4 & 3.2 & 6.4 & 123 & 1.7 & 358 & النواورة & \\
\hline 96 & & 100.0 & 100 & 1934 & 100 & 20604 & & الاجمالئ \\
\hline
\end{tabular}




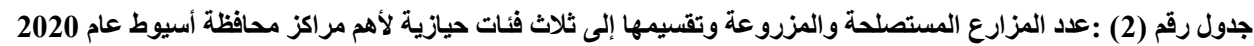

\begin{tabular}{|c|c|c|c|c|}
\hline جملة المزارع بالمركز & الفئة الحيازية الثالثة أكبر من 20 & الفئة الحيازية الثانية أكبر من 10 & الفئة الحيازية الأولى أقل من 10 & المركز \\
\hline 56 & 22 & 9 & 25 & الفتح \\
\hline 20 & 8 & 7 & 5 & منفلوط \\
\hline 13 & 4 & 4 & 5 & ديروط \\
\hline 7 & 3 & 1 & 3 & البدارى \\
\hline 96 & & & & الجملة \\
\hline
\end{tabular}

المصدر :جمعت وحسبت من أستمارة الأستبيان

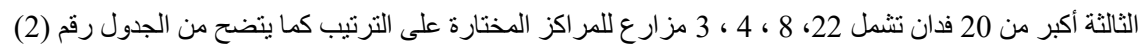

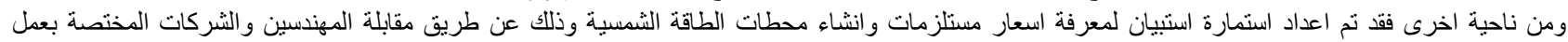
المحطات المخصصة بمضخات المياة بالطاقة الشمسية مكونات محطة الطاقة الثمسية:(7)، (8) الثان

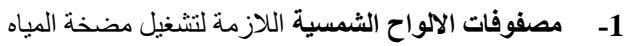

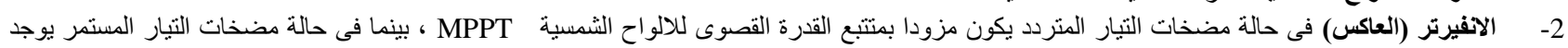
المتتبع مستقلات الميان

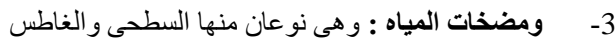

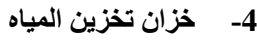

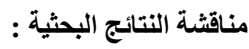

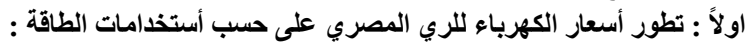

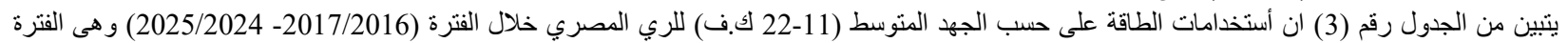

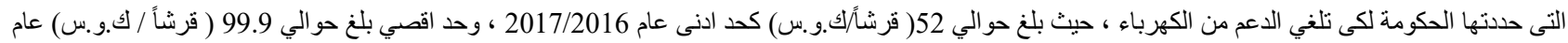

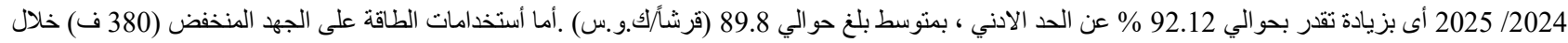

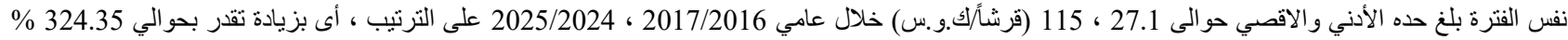

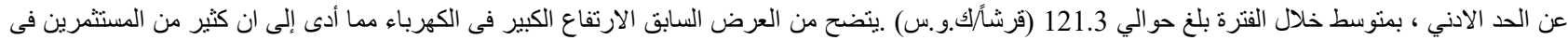

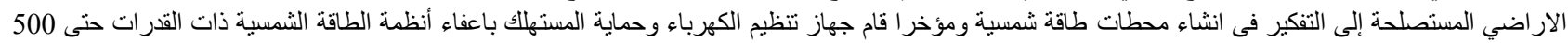

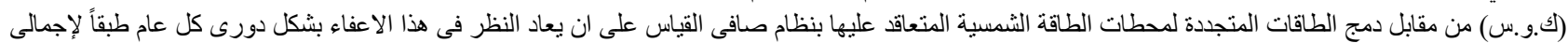

القدرات المركبة وطبقاً للقو اعد التنظيمية المطبقة في حينة .

جدول رقم (3): تطور أسعار الكهرباء بالكيلووات لكل ساعة (ك.و.س) للري المصري على حسب أستخدامات الطاقة موزعة على كل من الجهالمتوسط (11-2011 ك.ف)

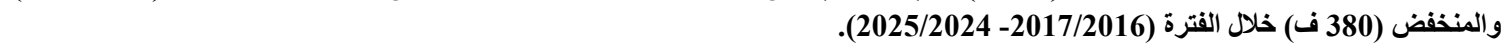

\begin{tabular}{|c|c|c|c|c|c|c|c|c|c|c|}
\hline \multicolumn{5}{|c|}{ استخذامات الطاقة على الجهُ المنخفض (380 ف) } & \multicolumn{5}{|c|}{ استخذامات الطاقة على الجهـ المتوسط (11-22 ك.ف) } & \multirow{6}{*}{ السنة } \\
\hline مقابل & داخل الأروة & خارج & متوسط & مقابل & مقابل خدمة & داخل الذروة & خارج & متوسط & مقابل القدرة & \\
\hline 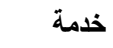 & (قرش/ك.و. & 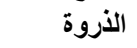 & سعر الطاقة & 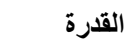 & 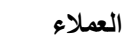 & (قرش/ك.و. & 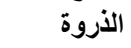 & سعر الطاقة & (جنية/ك.و. & \\
\hline 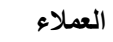 & س) & (قرش/ك.و. & (قرش/ك.و. & (جنية/ك.و. & جنية/مشتر & س) & (قرش/ك.و. & (قرش/ك.و. & 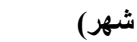 & \\
\hline جنية/مشت & & س) & 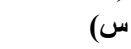 & شهر) & ك - شهر & & 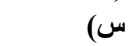 & & & \\
\hline \multicolumn{10}{|l|}{ رك -شهر } & \\
\hline & & & 27.1 & - & 30 & 72 & 48 & 52 & 45 & $/ 2016$ \\
\hline & & & & & & & & & & 2017 \\
\hline \multirow[t]{2}{*}{4} & & & 35 & - & 35 & 106.2 & 70.8 & 76.7 & 50 & $/ 2017$ \\
\hline & & & & & & & & & & 2018 \\
\hline \multirow[t]{2}{*}{4} & & & 50 & - & 35 & 111 & 74 & 80 & 30 & $/ 2018$ \\
\hline & & & & & & & & & & 2019 \\
\hline \multirow[t]{2}{*}{4} & & & 75 & - & 35 & 138.3 & 92.2 & 99.9 & 60 & $/ 2019$ \\
\hline & & & & & & & & & & 2020 \\
\hline \multirow[t]{2}{*}{4} & & & 85 & - & 35 & 138.3 & 92.2 & 99.9 & 60 & $/ 2020$ \\
\hline & & & & & & & & & & 2021 \\
\hline \multirow[t]{2}{*}{4} & & & 95 & - & 35 & 138.3 & 92.2 & 99.9 & 60 & $/ 2021$ \\
\hline & & & & & & & & & & 2022 \\
\hline \multirow[t]{2}{*}{4} & & & 105 & - & 35 & 138.3 & 92.2 & 99.9 & 60 & $/ 2022$ \\
\hline & & & & & & & & & & 2023 \\
\hline \multirow[t]{2}{*}{4} & & & 115 & - & 35 & 138.3 & 92.2 & 99.9 & 60 & $/ 2023$ \\
\hline & & & & & & & & & & 2024 \\
\hline \multirow[t]{2}{*}{4} & & & 121.3 & - & 35 & 138.3 & 92.2 & 99.9 & 60 & $/ 2024$ \\
\hline & & & & & & & & & & 2025 \\
\hline 4 & & & 78.7 & - & 34.4 & 124.3 & 82.9 & 89.8 & 53.9 & المتوسط \\
\hline
\end{tabular}


ثانياً : احتياجات المحاصيل المائية اليومية للاراضي المستصلحة المزروعة لأهم مراكز محافظة أسيوط : 1

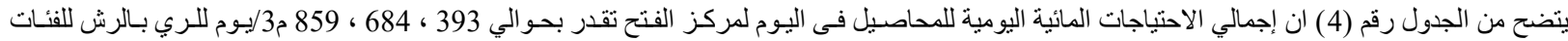

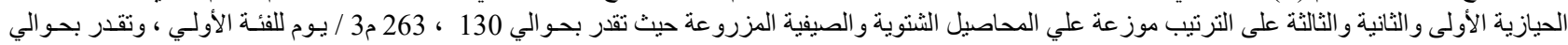

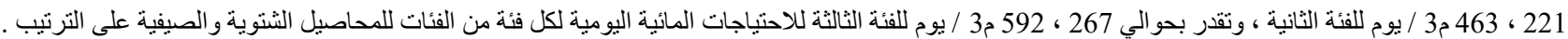
أما بالنسبة إلى الاحتياجات

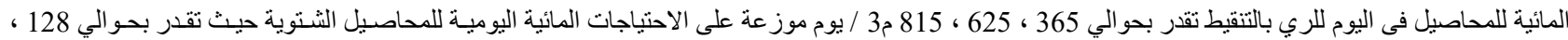
211 ، 261 م3 / يوم للفئات الحيازية الثلاثة على الترتيب ، فئلئ حين ان هذه الاحتياجات للمحاصيل الصيفية تقدر بحو الي 365 ، 625 ، 625 ، 815 م3 / يوم على الترتيب للفئات

جدول رقم (4): الاحتياجات المائية اليومية م3 / فدان لأهم المحاصيل المزروعة بمركز الفتح للفئات الحيازية الثلاثة للاراضي المستصلحة المزروعة تحت انظمة الرى )

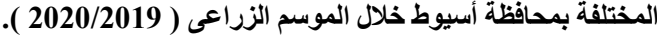

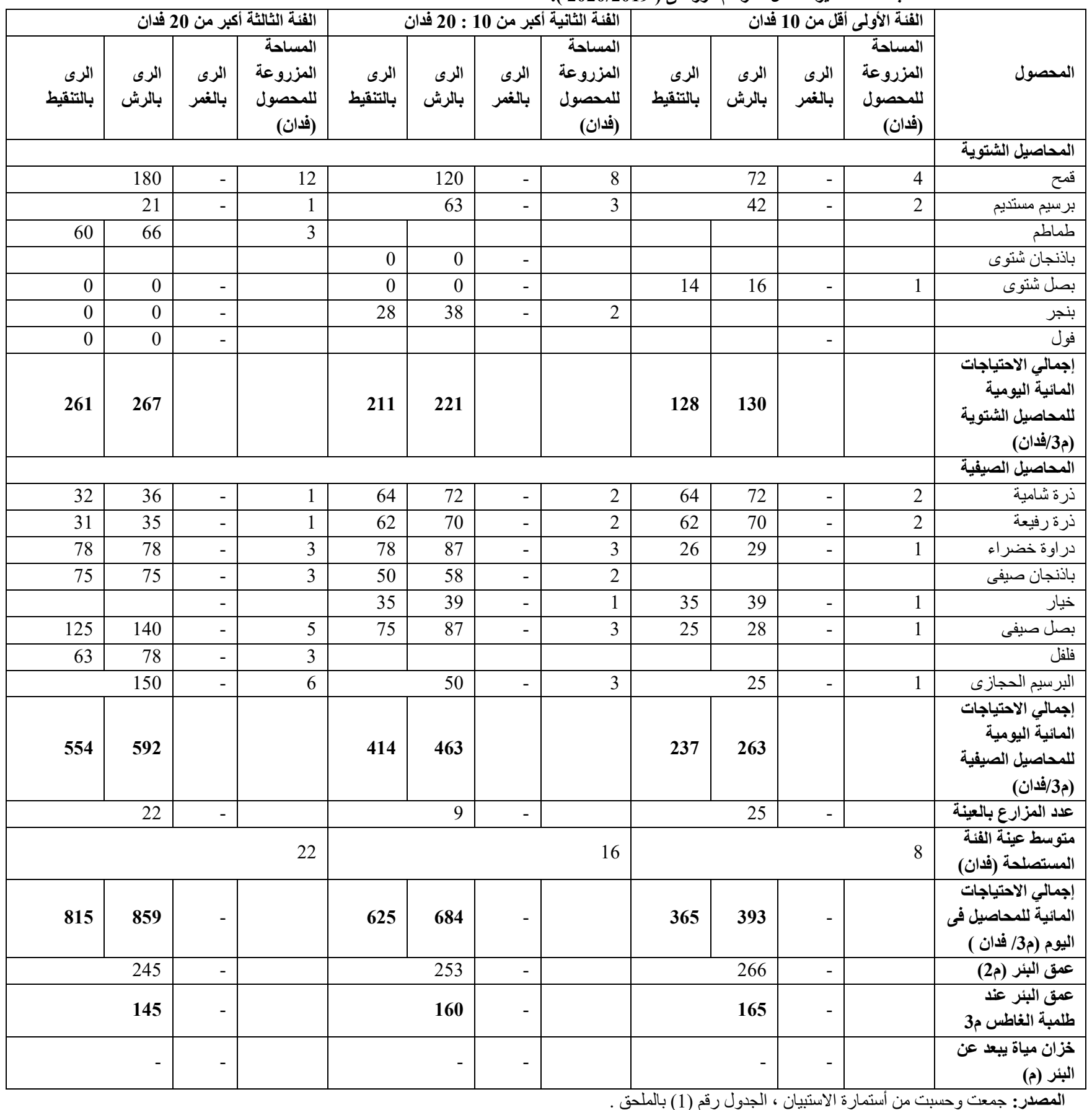

الحيازية السابقة خلال الموسم الزر اعي 2019/ 2020 ـ أما طريقة الري بالغمر فى مركز الفتح لا تستخدم فى ري المحاصيل حيث تتطلب هذه الطريقة تكساليف عاليـة للحصول على الطاقة من ناحية و عدم استو اء الار اضي المستصلحة من ناحية أخري . 


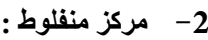

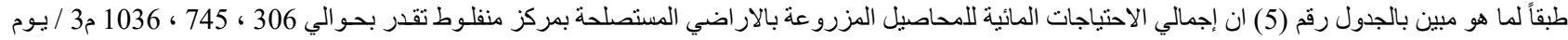
لطريقة الري بالرش ، في حين تقدر بحو الي 279 ، 670 ، 986 م3 / يوم بطريقة الري بالتنقيط على الترتيب للفئات الحيازية الثلاثة للموسم الزر اعي (2020/2019) ،

جدول رقم (5): الاحتياجات المائية اليومية م3 / فدان لأهم المحاصيل المزروعة بمركز منفلوط للفئات الحيازية الثلاثة للار اضي المستصلحة المزروعة تحت انظمة الرى (لئ

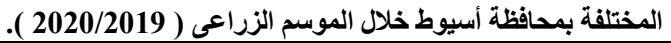

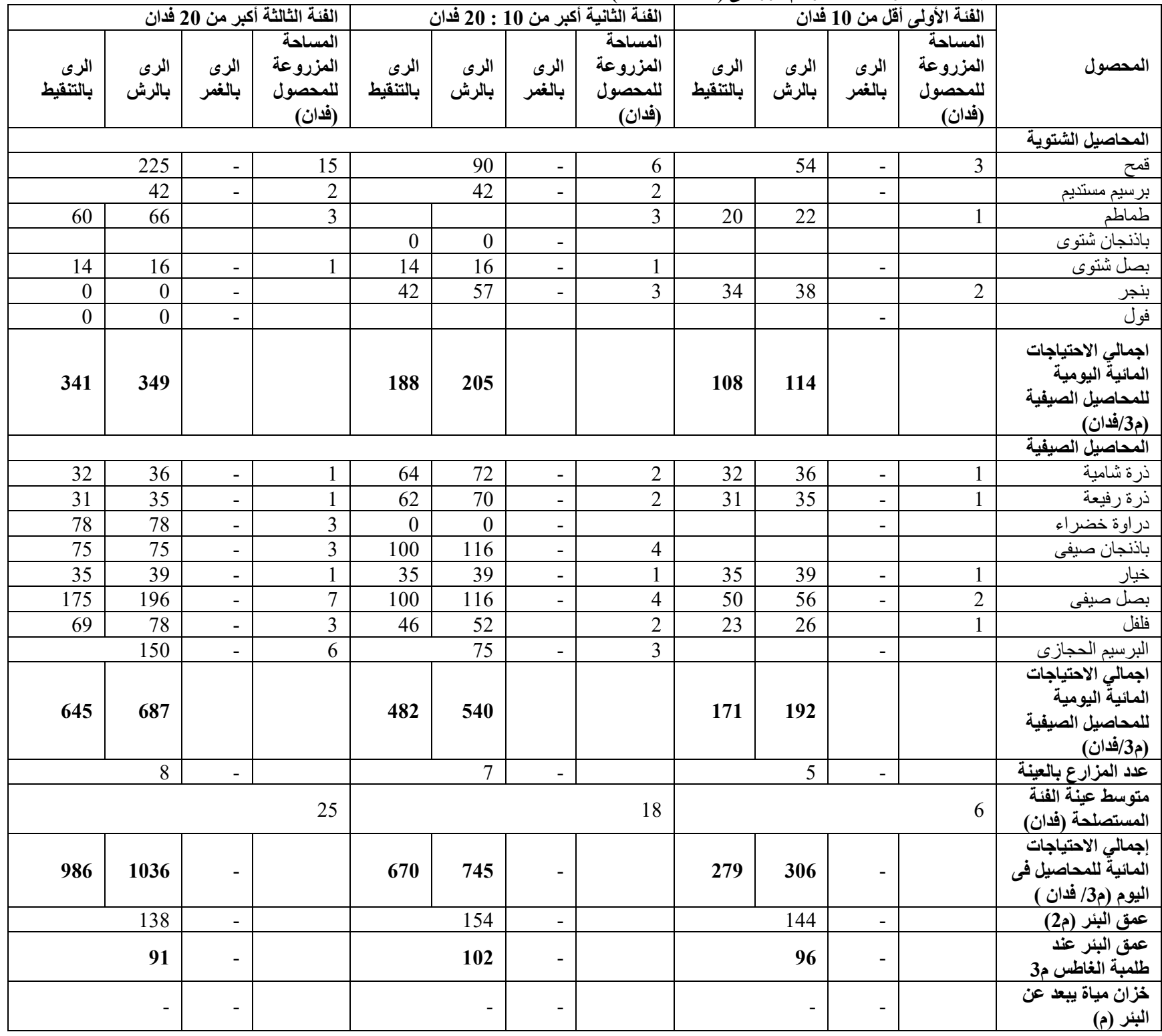

المصدر: جمعت وحسبت من أستمارة الاستبيان ، الجدول رقم (1) بالملحق .

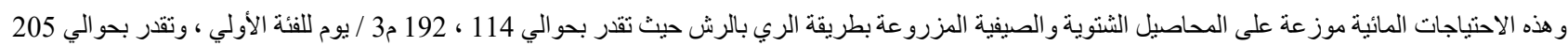

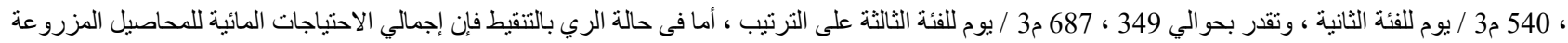

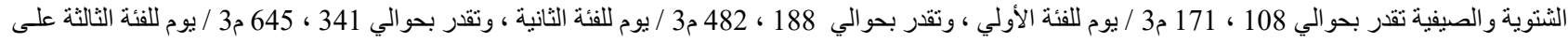

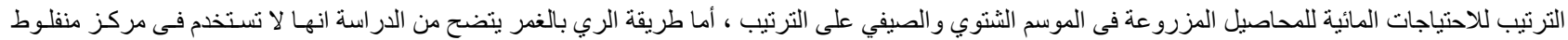

وذللك لنفس الاسباب الموضحة سابقاً .

:

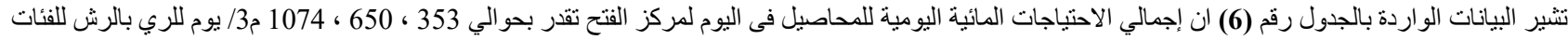

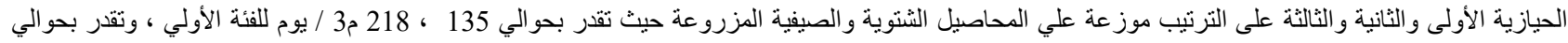

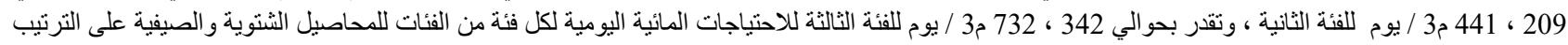

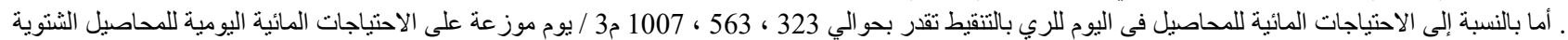

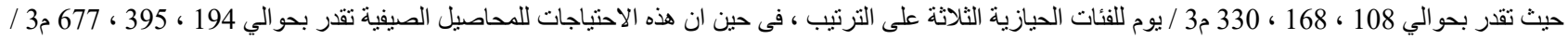

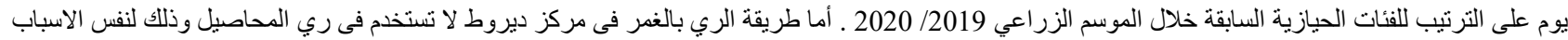
الموضحة سابقاً. 
جدول رقم (6): الاحتياجات المائية اليومية م3 / فدان لأهم المحاصيل المزروعة بمركز ديروط للفئات الحيازية الثثلاثة للاراضي المستصلحة المزروعة تحت انظمة الرىى

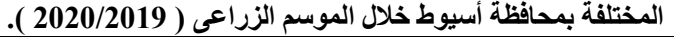

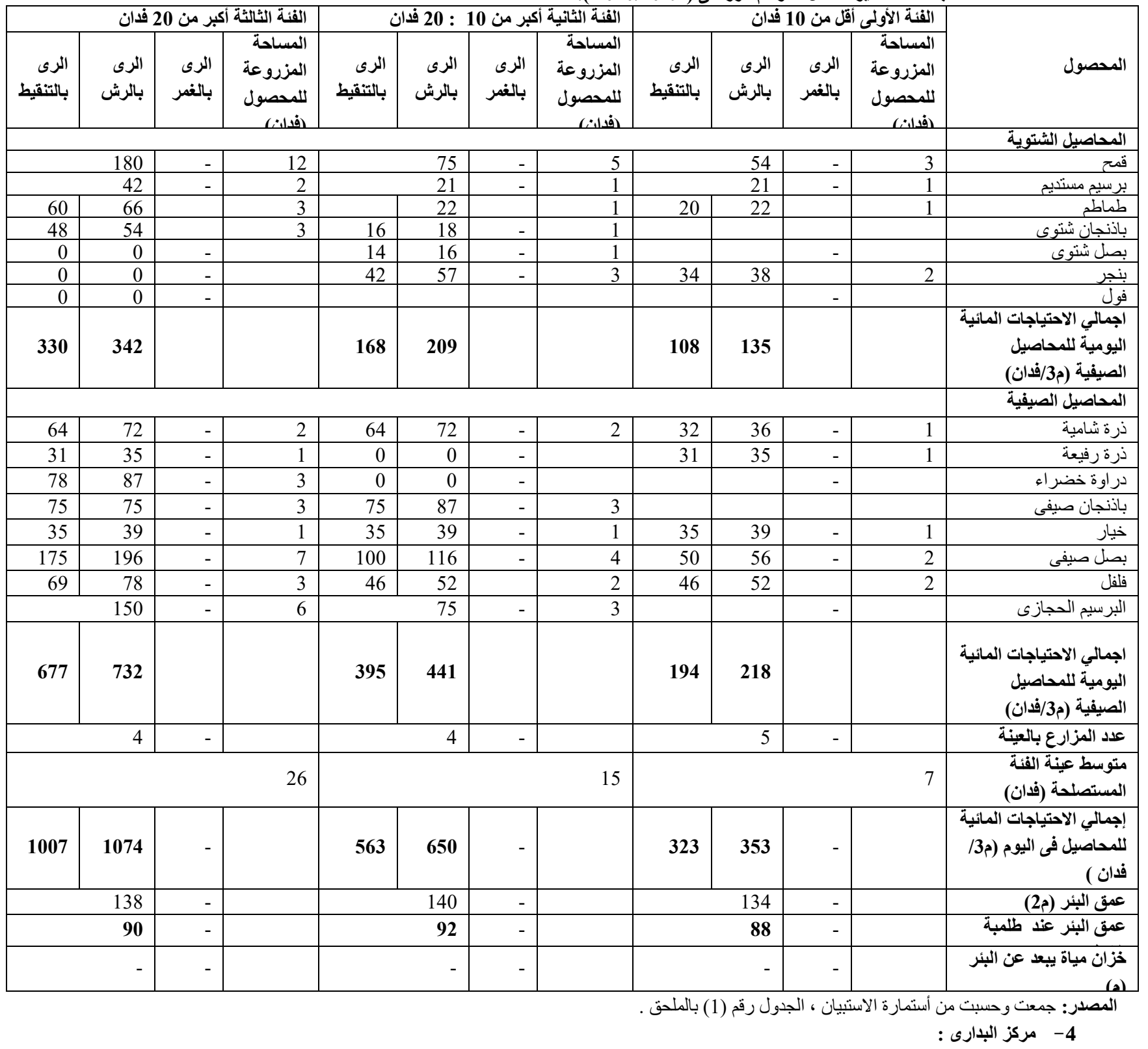

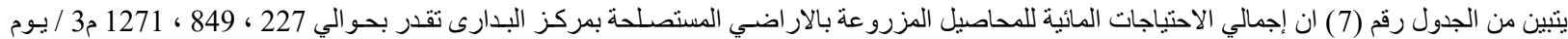

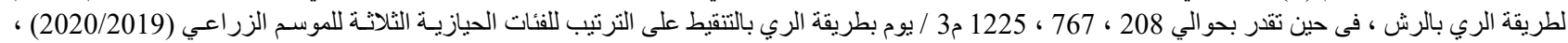

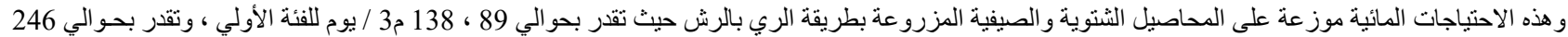

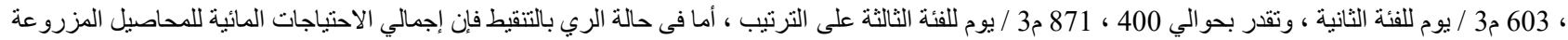

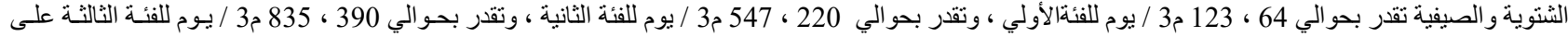

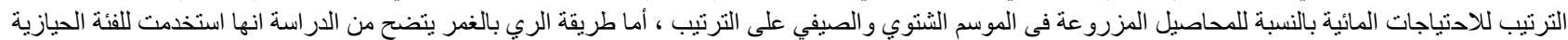

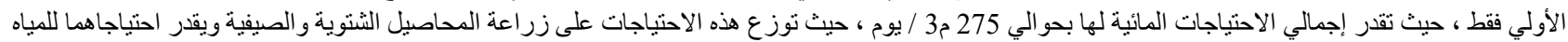

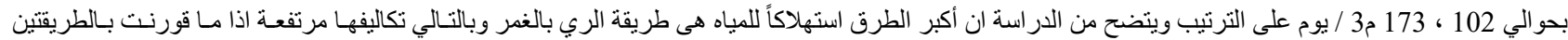

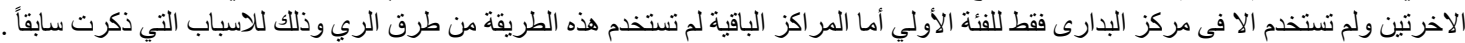

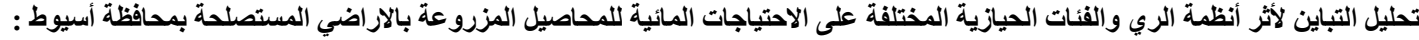

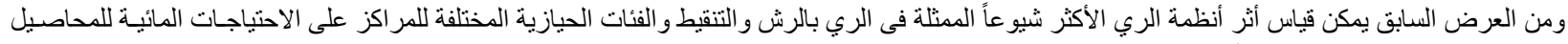

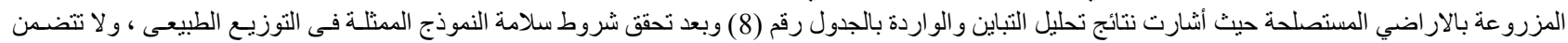

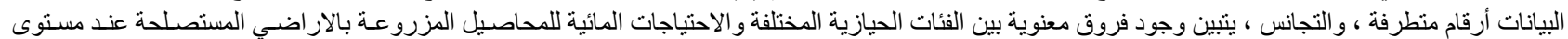

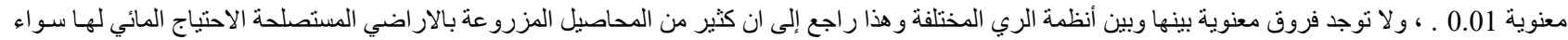

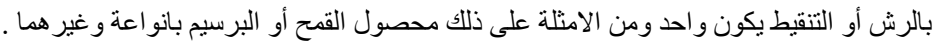


جدول رقم (7): الاحتياجات المائية اليومية م3 / فدان لأهم المحاصيل المزروعة بمركز البدارى للفئات الحيازية الثلاثة للاراضي المستصلحة|لمزروعة تحت انظمة الرى (المي المختلفة بمحافظة أسيوط خلال الموسم الزراعي الاعل ( 2020/2019 ).

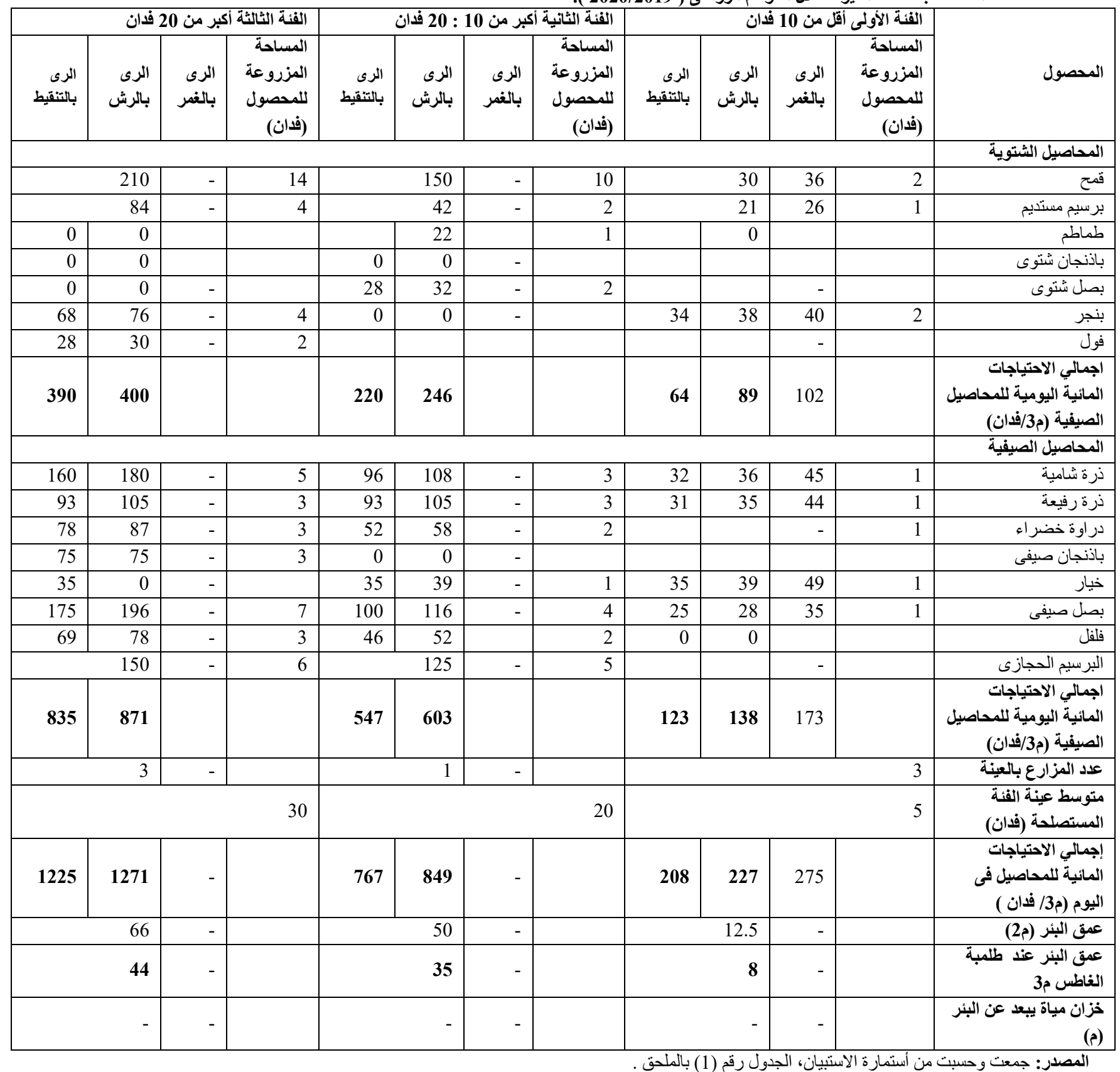

جدول رقم (8): تحليل التباين فى اتجاهين لاختبار اثر أنظمة الري والفئات الحيازية المختلفة على الاحتياجات المائية للمحاصيل بالاراضي المستصلحة بمحافظة أسيوط خلال الموسم الزراعى ( 2020/2019 )

\begin{tabular}{|c|c|c|c|c|}
\hline قيمة ف المحسوبة & متوسط مربع الأنحر افات & درجات الحرية & مجموع مربعات الأحر افات & مصدر الاختلاف \\
\hline 1.273 & 15708.167 & 1 & 15708.167 & بين أنظمة الري المختلفة \\
\hline$* 85.881$ & 1059645.042 & 2 & 2119290.083 & بين الفئات الحيازية المختلفة \\
\hline & 12338.554 & 20 & 246771.083 & 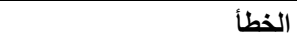 \\
\hline & & 23 & 2381769.333 & المجموع \\
\hline
\end{tabular}

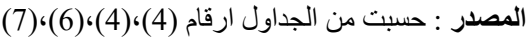

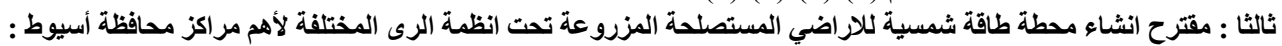

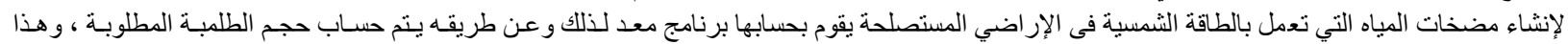

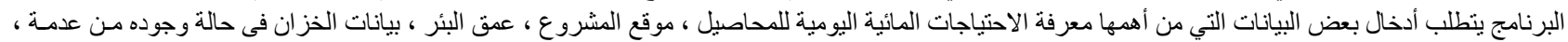

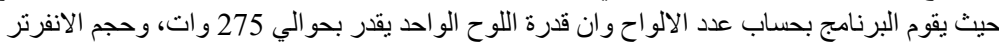

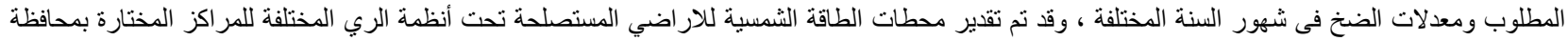
أسيوط وفيما يلي توضيح ذللك : 
1

يتبين من الجدول رقم (9) ان إجمالي ضيخ المياه السنوي للنظام الذي يعمل بالطاقة الثمسية لهركز الفتح يبلغ حوالي

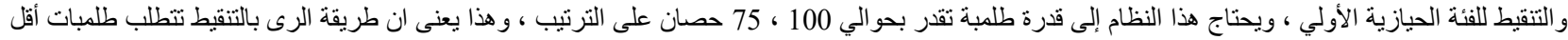

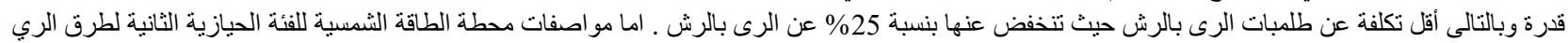

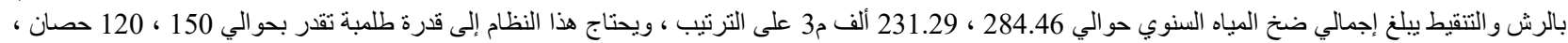

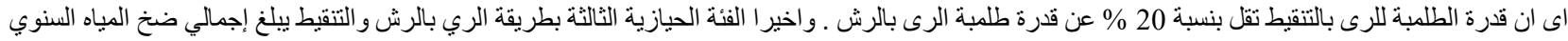

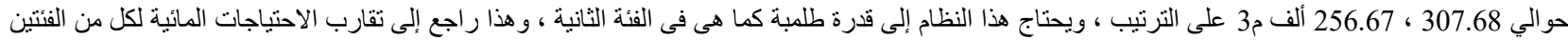

وزر اعتها بنفس المحاصيل الموجودة بالفئة الثانية

جدول رقم (9): مواصفات محطة الطاقة الثمسية المقترحة للاراضي المستصلحة المزروعة تحت انظمة الرى المختلفة لمركز الفتح بمحافظة أسيوط عام 2021 المئر

\begin{tabular}{|c|c|c|c|c|c|c|c|c|c|c|c|c|c|}
\hline \multicolumn{4}{|c|}{ الفئة الثالثة أكبر من 20 فدان } & \multicolumn{4}{|c|}{ الفئة الثانية أكبر من 10 : 20 فـان } & \multicolumn{4}{|c|}{ الفئة الأولى أقل من 10 فدان } & \multirow{2}{*}{ القياس } & \multirow[t]{2}{*}{ البيان } \\
\hline \multicolumn{2}{|c|}{ الرى بالتنقيط } & \multicolumn{2}{|c|}{ الرى بالرش - ل الرش } & \multicolumn{2}{|c|}{ الرى بالتنقيط } & \multicolumn{2}{|c|}{ الرى بالرش - ل الرش } & \multicolumn{2}{|c|}{ الرى بالتنقيط } & \multicolumn{2}{|c|}{ الرى بالرش - ل الرش } & & \\
\hline \multirow{2}{*}{\multicolumn{2}{|c|}{167.96}} & & & & & & & & & & & & بيانات الطلمبة \\
\hline & & \multicolumn{2}{|c|}{169.3} & \multicolumn{2}{|c|}{186.39} & \multicolumn{2}{|c|}{183.12} & \multicolumn{2}{|c|}{192.27} & \multicolumn{2}{|c|}{193.41} & ? & ارتفاع الضخ الديناميكي \\
\hline \multicolumn{2}{|c|}{117} & \multicolumn{2}{|c|}{143} & \multicolumn{2}{|c|}{104} & \multicolumn{2}{|c|}{114} & \multicolumn{2}{|c|}{61} & \multicolumn{2}{|c|}{66} & مج/ساعة & معدل تدفق المياه للطلمبة \\
\hline \multicolumn{2}{|c|}{120} & \multicolumn{2}{|c|}{150} & & 20 & & 50 & & & & & حصان & قلرة الطلمبة بالحصان \\
\hline & 26 & & 6 & & 8 & & 8 & & & & & مرحلة & عدد مر احل المضخة \\
\hline & 6 & & 6 & & 5 & & 6 & & & & & بوصة & قطر ماسورة الطرد \\
\hline & 1.84 & & 25 & & 36 & & 79 & & & & & م/ثانية & سر عاسة تدفق المياه في \\
\hline 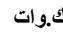 & بقارة 18.8 & 1 & بقارة 3.55 & ك.كات & 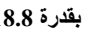 & ك.وات & بقارة 13.5 & 7 ك.وات & بقدرة 25 & ك.وات & بقارة 9 & & مواصفات المحطة \\
\hline بقدرة & لتثغيل مض & كة بقدرة & لتشغيل مض & لة بقدرة & لتشغيل مض & لة بقدرة & لتشغيل مض & بقلدرة 75 & لتشغيل مض & خة بقدرة & لتشغيل مد & & الثمسية \\
\hline & 2120 & & 150 & & 120 & & 150 & & & صان & & & \\
\hline & & & & & & & & & & & & & بيانات الموقع و حجم النظام \\
\hline & 956 & & 56 & & 56 & & 56 & & & & & (5.9.9.) & ألأشعاع الثمسي السنوي \\
\hline & 1113 & & 113 & & 1113 & & 1113 & & & & & شمال & خط العرض \\
\hline & .7531 & & 7531 & & 7531 & & 7531 & & & & & 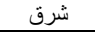 & خط الطول \\
\hline & 6.67 & & 7.68 & & .29 & & 1.46 & & & & & 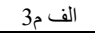 & اجمالي ضخ المياه السنوي \\
\hline & & & & & 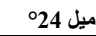 & ب ل للمياهزا & 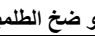 & مسية للكهر؛ & ن التاج الالواح & & & & \\
\hline ضن & انتاج & ضن & انتاج & ضخ & انتاج & ضخ & انتاج & ضخ مياه & انتاج & ضخ مياه & انتاج & اشعاع المعاع & الثهر \\
\hline مياه & كهرباء & مياه & كهرباء & مياه & كهرباء & مياه & كهرباء & يومي & كهرباء & يومي & كهرباء & شمسي & \\
\hline يومي & يومي & 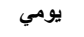 & يومي & يومي & يومي & يومي & يومي & بالمتر & يومي & بالمتر & يومي & SI & \\
\hline بالمتر & (ك.و.س) & بالمتر & (5.9.9. (5) & بالمتر & (5.9.9.5) & بالمتر & (5.9.5.5) & المكب & (ك.و.س) & المكب & (5.9.س) & & \\
\hline 505 & 385 & 605 & 465.1 & 455 & 384.9 & 559 & 465.1 & 276 & 240.6 & 365.2 & 320.8 & 4.32 & بناير \\
\hline 637 & 486 & 763 & 586.8 & 574 & 485.6 & 706 & 586.8 & 348 & 303.5 & 460.7 & 404.7 & 5.45 & فبراير \\
\hline 759 & 579 & 910 & 699.8 & 684 & 579.2 & 841 & 699.8 & 415 & 362 & 549.4 & 482.6 & 6.5 & مارس \\
\hline 785 & 599 & 941 & 723.5 & 707 & 598.8 & 870 & 723.5 & 429 & 374.2 & 568 & 499 & 6.72 & ابريل \\
\hline 790 & 602 & 947 & 727.8 & 712 & 602.3 & 875 & 727.8 & 431 & 376.4 & 571.4 & 501.9 & 6.76 & مايو \\
\hline 820 & 626 & 983 & 755.8 & 739 & 625.5 & 909 & 755.8 & 448 & 390.9 & 593.4 & 521.2 & 7.02 & يونيو \\
\hline 819 & 625 & 982 & 754.7 & 738 & 624.6 & 908 & 754.7 & 447 & 390.4 & 592.5 & 520.5 & 7.01 & يوليو \\
\hline 820 & 626 & 983 & 755.8 & 739 & 625.5 & 909 & 755.8 & 448 & 390.9 & 593.4 & 521.2 & 7.02 & اغسطس \\
\hline 800 & 610 & 959 & 737.5 & 721 & 610.3 & 887 & 737.5 & 437 & 381.5 & 579 & 508.6 & 6.85 & سبتمبر \\
\hline 702 & 536 & 842 & 647.1 & 633 & 535.5 & 778 & 647.1 & 383 & 334.7 & 508 & 446.2 & 6.01 & اكتوبر \\
\hline 536 & 409 & 643 & 494.2 & 483 & 409 & 594 & 494.2 & 293 & 255.6 & 388 & 340.8 & 4.59 & نوفمبر \\
\hline 465 & 355 & 557 & 428.5 & 419 & 354.6 & 515 & 428.5 & 254 & 221.6 & 336.4 & 295.5 & 3.98 & ديسمبر \\
\hline
\end{tabular}

\begin{tabular}{|c|c|c|c|c|c|c|c|}
\hline & & & & & & & Inverter الأنفرتر \\
\hline المواصفة & المواصفة & المواصفة & المواصفة & المواصفة & المواصفة & وحدة القيس & رقم \\
\hline $800-450$ & $800-450$ & $800-450$ & $800-450$ & $800-450$ & $800-450$ & $\mathrm{~V}$ & نطاق جهد للخلأيا الثمسية \\
\hline 90 & 110 & 90 & 110 & 55 & 75 & $\mathrm{KW}$ & Rated Power القدرة \\
\hline 380 & 380 & 380 & 380 & 380 & 380 & فولت - الت & جهد التيار المتردد الخارج \\
\hline $60 / 50-0$ & $60 / 50-0$ & $60 / 50-0$ & $60 / 50-0$ & $60 / 50-0$ & $60 / 50-0$ & هرتز & Frequency التردد \\
\hline 3 & 3 & 3 & 3 & 3 & 3 & , & عدد الفاز ات \\
\hline 169 & 204 & 169 & 204 & 106 & 141 & امبير - ل امبير & Rated Current قصي تبال \\
\hline & & & & & & & تصيم الألو اح الثمسية \\
\hline الكمية & الكمية & الكمية ل الكية & الكمية & الكمية & الكمية ل الكية & ودة القيس & البند \\
\hline 275 & 275 & 275 & 275 & 275 & 275 & وات & قدرة اللوح الثُمسي الواحد \\
\hline 24 & 29 & 24 & 29 & 15 & 20 & مصفوفة & عدد مصفو فات الألو اح \\
\hline 18 & 18 & 18 & 18 & 18 & 18 & لوح ال لوح & عدد الألواح في كل مصفوفة \\
\hline 4950 & 4950 & 4950 & 4950 & 4950 & 4950 & وات & قدرة المصفوفة الو احدة \\
\hline 432 & 522 & 432 & 522 & 270 & 360 & لوح & اجمالي عدد الألواح الثمسية \\
\hline 118.8 & 143.55 & 118.8 & 143.55 & 74.25 & 99 & كيلو وات & اجمالي قدرة الألواح الشمسية \\
\hline${ }^{\circ} 180$ & ${ }^{\circ} 180$ & ${ }^{\circ} 180$ & ${ }^{\circ} 180$ & ${ }^{\circ} 180$ & ${ }^{\circ} 180$ & الجنوب & توجية الألو اح الثمسية \\
\hline${ }^{\circ} 24$ & ${ }^{\circ} 24$ & ${ }^{\circ} 24$ & ${ }^{\circ} 24$ & ${ }^{\circ} 24$ & ${ }^{\circ} 24$ & عن المستوي & زاوية ميل الألو اح \\
\hline
\end{tabular}




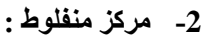

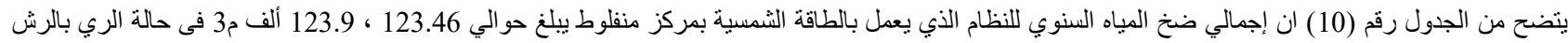

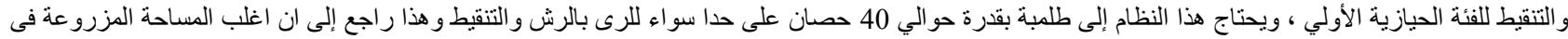

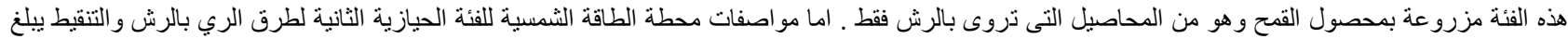

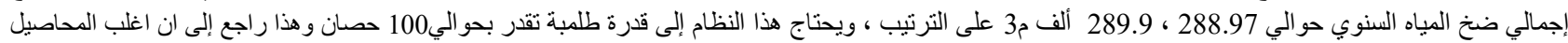

المزروعة

جدول رقم (10): مواصفات محطة الطاقة الثمسية المقترحة للاراضي المستصلحة المزروعة تحت انظمة الرى المختلفة لمركز منفلوط بمحافظة أسيوط عام 2021

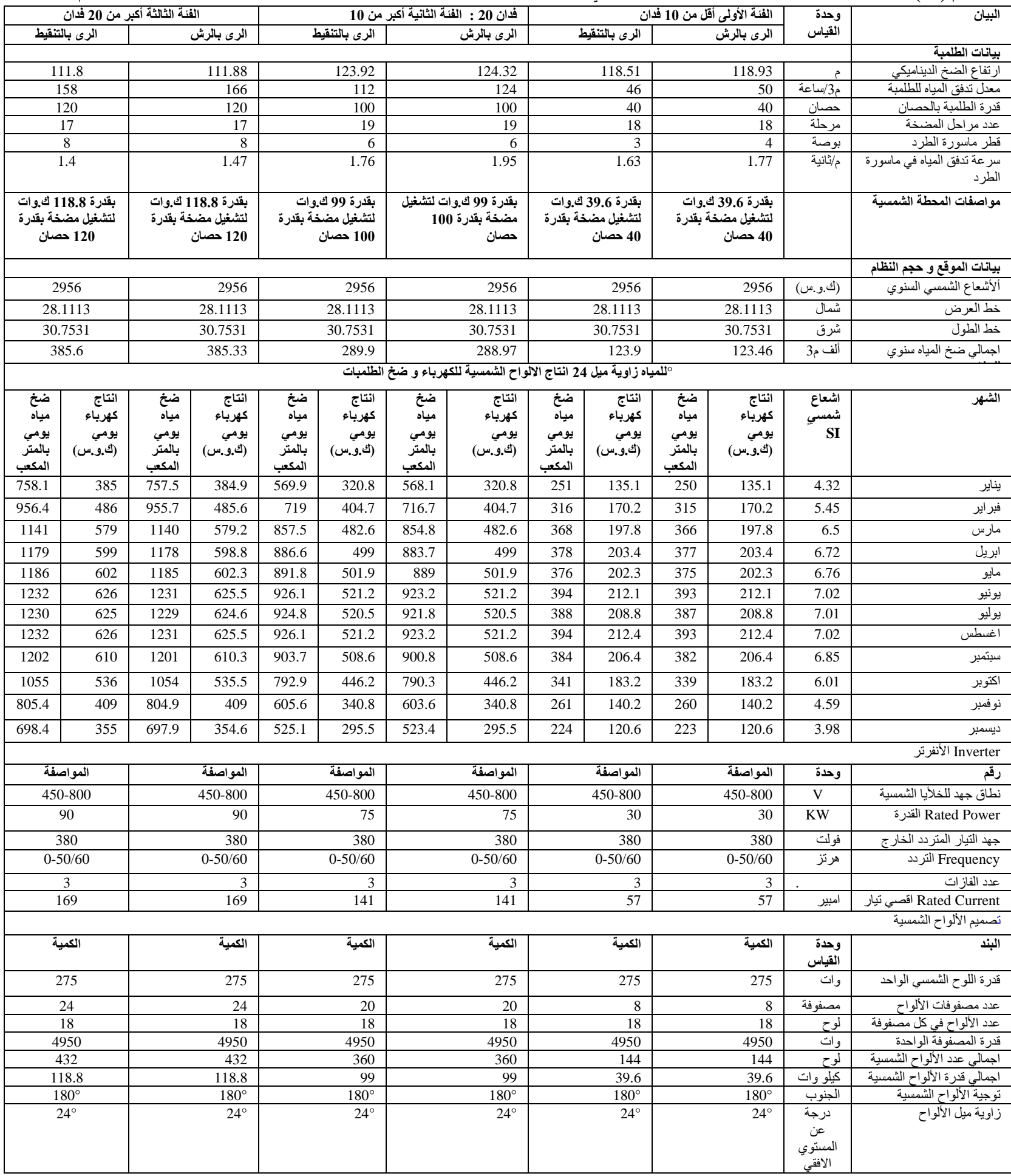

المصدر :حسبت عن طريق برنامج طلمبات الطاقة الثنمسية على حسب الاحتياج المائى للمحاصيل.

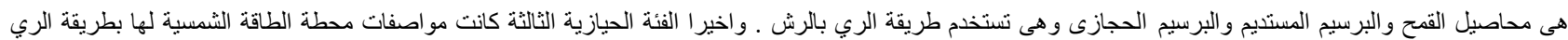

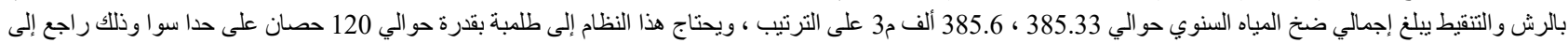




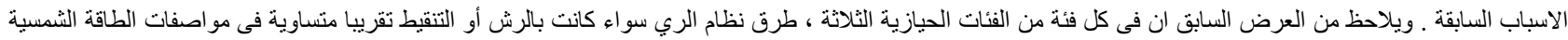

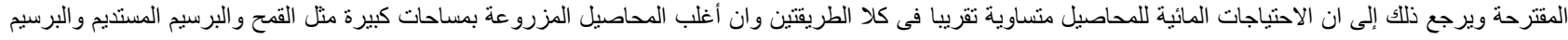

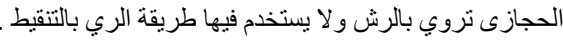

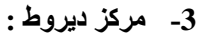

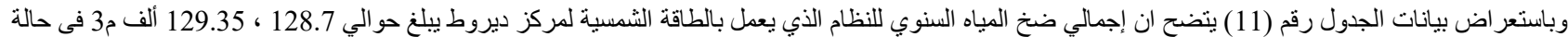

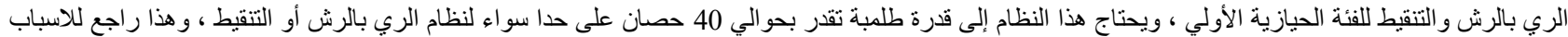

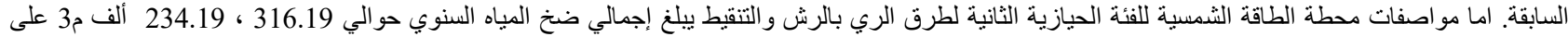

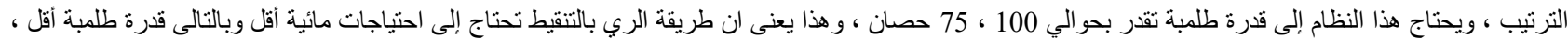

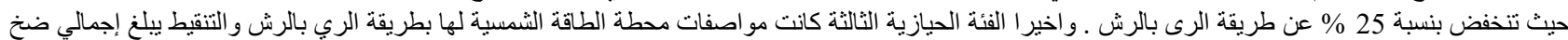

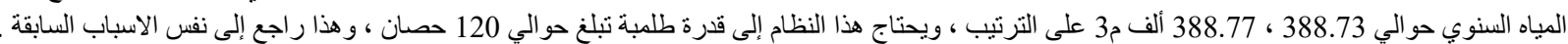

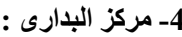

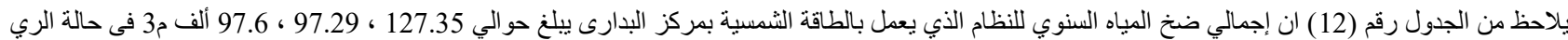

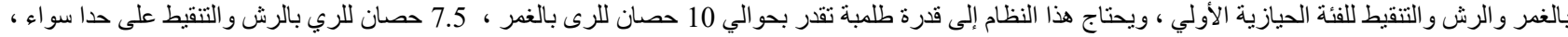

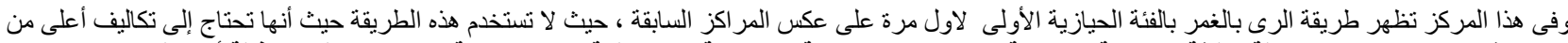

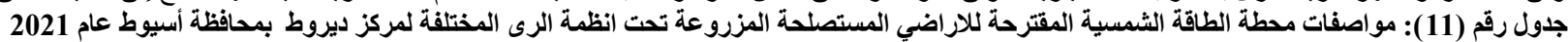

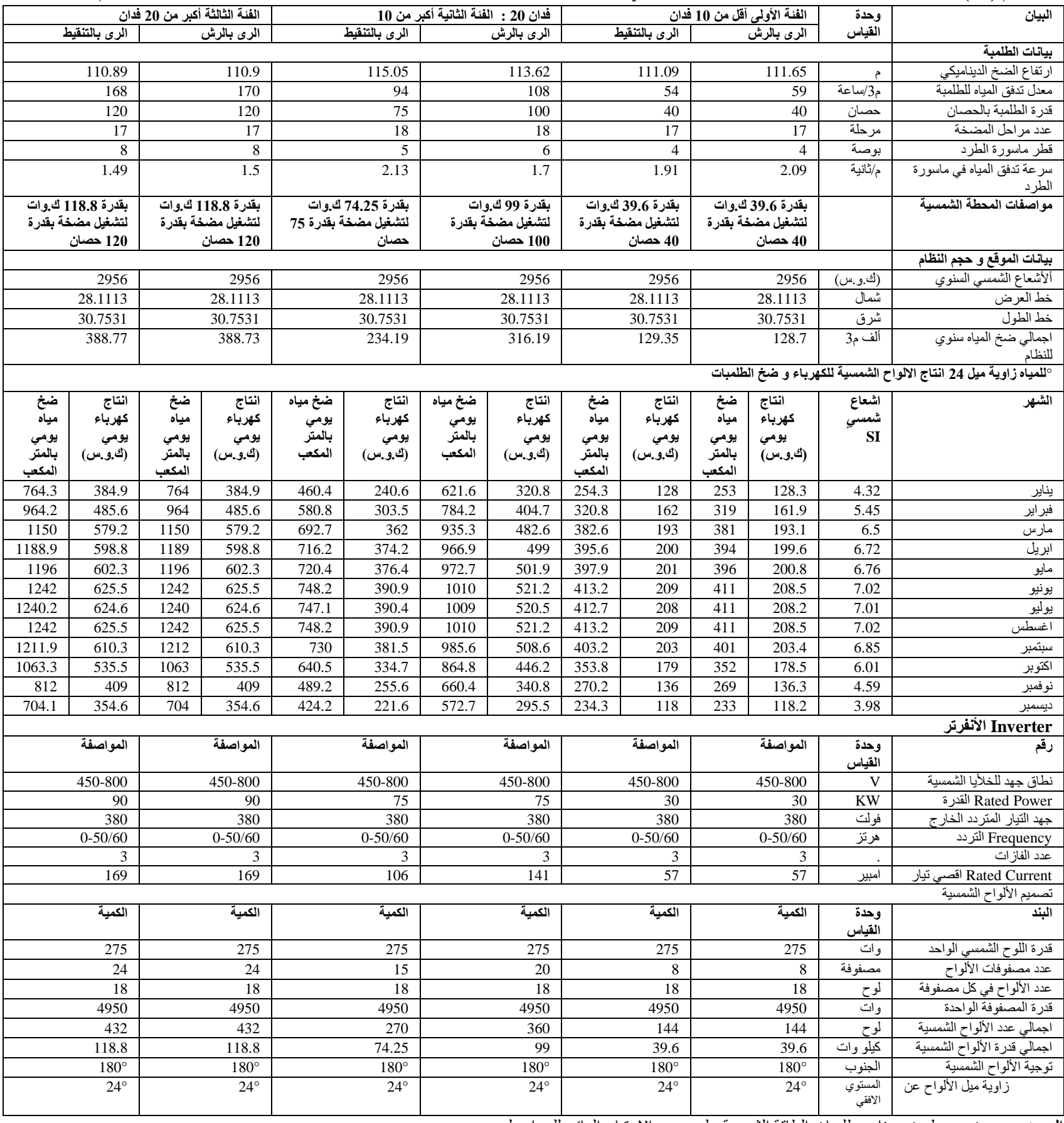


جدول رقم (12): مواصفات محطة الطاقة الثمسية المقترحة للاراضي المستصلحة المزروعة تحت انظمة الرى المختلفة لمركز البدارى بمحافظة|سيوط عام 2021 المنام

\begin{tabular}{|c|c|c|c|c|c|c|c|c|}
\hline \multicolumn{2}{|r|}{ أكبر من 20 فدان } & \multicolumn{2}{|c|}{ الفئة الثانية أكبر من 10 : 20 فـان } & \multicolumn{3}{|c|}{ الفئة الأولى أقل من 10 فـان } & \multirow{2}{*}{ القياسة } & \multirow[t]{2}{*}{ 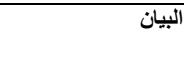 } \\
\hline الرى بالتنقيط & الرى بالرش & الرى بالتتقيط & الرى بالرش & الرى بالتنقيط & 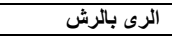 & الرى بالغر & & \\
\hline & & & & & & & & بيانات الطلمبة \\
\hline 64.53 & 64.56 & 55.84 & 56.02 & 28.63 & 28.72 & 28.21 & م & ارتفاع الضخخ الديناميكي \\
\hline 188 & 194 & 128 & 142 & 39 & 42 & 46 & ساعة & للطعدلة تدفق المياه \\
\hline 100 & 100 & 50 & 50 & 7.5 & 7.5 & 10 & حصان & قدرة الطلمبة بالحصان \\
\hline 10 & 10 & 9 & 9 & 5 & 5 & 5 & مرحلة - مرحة & عدد مر احل المضخة \\
\hline 8 & 8 & 6 & 6 & 3 & 3 & 4 & بوصة & قطر ماسورة الطرد \\
\hline 1.66 & 1.72 & 2.01 & 2.23 & 2.45 & 2.64 & 1.63 & ماثثانية & ماسور عة الطفر المباه في \\
\hline بتشغيل مضخة 99 ك.واتدرة 100 حصان & لتشغيل مضخة 99 ك.واتدرة 100 حصان & 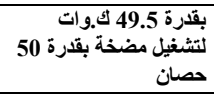 & 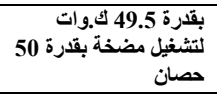 & 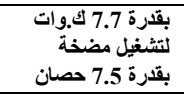 & بقتشغرة مضخة 7.7 ك.وات & 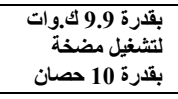 & & الثمواصفيةت المحطة \\
\hline & & & & & & & & إنظانات الموقع و حجم \\
\hline 2956 & 2956 & 2956 & 2956 & 2956 & 2956 & 2956 & 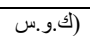 & ألأشعاع الشمسي \\
\hline 28.1113 & 28.1113 & 28.1113 & 28.1113 & 28.1113 & 28.1113 & 28.1113 & شمال & خط العرض \\
\hline 30.7531 & 30.7531 & 30.7531 & 30.7531 & 30.7531 & 30.7531 & 30.7531 & 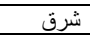 & خط الطول \\
\hline 556.72 & 556.46 & 321.67 & 320.65 & 97.6 & 97.29 & 127.35 & ألف م3 & اجمالي ضنار المياه \\
\hline & & & & & & طلمبات للمياه زاوية مياز & ل باءو و ضخ & انتاج الالواح الثشسية لا \\
\hline 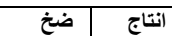 & انتاج & ضخ مياه & ضخ مياه & انتاج & انتاج & انتاج & اشعاع & الثهر \\
\hline كهرباء & كهرباء & يومي بَالمتر & كهربًاء & كهربّاء كري & كهربّاء كري & كهربّاء كري & شسيّي & \\
\hline يوبمتر & يو.وئ) & يو.ومي) & 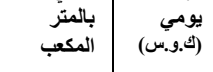 & (يومئس) & (يومئي) & يوئي) & SI & \\
\hline المكب & المكب & 632.4 & 160.4 & $\begin{array}{l}\text { المكب } \\
192\end{array}$ & المكب & المكب & 4.32 & يناير \\
\hline 1381 & 1380 & 797.8 & 202.3 & 31.5 & 31.5 & 40.5 & 5.45 & فيراير ت فير \\
\hline 1647 & 1646 & 951.5 & 241.3 & 37.5 & 37.5 & 48.3 & 6.5 & مارس - ماس \\
\hline 1703 & 1702 & 983.7 & 249.5 & 38.8 & 38.8 & 49.9 & 6.72 & 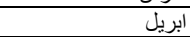 \\
\hline 1713 & 1712 & 989.6 & 251 & 300 & 299 & 50.2 & 6.76 & مايو \\
\hline 1779 & 1778 & 1028 & 260.6 & 40.5 & 40.5 & 52.1 & 7.02 & 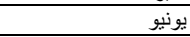 \\
\hline 1776 & 1775 & 1026 & 260.2 & 40.5 & 40.5 & 406 & 7.01 & يوليو \\
\hline 1779 & 1778 & 1028 & 260.6 & 40.5 & 40.5 & 52.1 & 7.02 & اغشطس \\
\hline 1735 & 1735 & 1003 & 254.3 & 39.6 & 39.6 & 50.9 & 6.85 & سبتمبر \\
\hline 1523 & 1522 & 879.8 & 223.1 & 34.7 & 34.7 & 44.6 & 6.01 & اكتوبر \\
\hline 1163 & 1162 & 671.9 & 170.4 & 26.5 & 26.5 & 34.1 & 4.59 & نوفمبر \\
\hline 1008 & 1008 & 582.6 & 147.8 & 177 & 176 & 29.6 & 3.98 & ديبمبر \\
\hline & & & & & & & & الآنفرتر Inverter \\
\hline المواصفة & المواصفة & المواصفة & المواصفة & المو اصفة & المو اصفة & المواصفة & القياسة & رقم \\
\hline $800-450$ & $800-450$ & $800-450$ & $800-450$ & $800-450$ & $800-450$ & $800-450$ & $\mathrm{~V}$ & نطاق جهـ للخلايا \\
\hline 75 & 75 & 37 & 37 & 5,5 & 5,5 & 7,5 & $\mathrm{KW}$ & Rated Power القدرة \\
\hline 380 & 380 & 380 & 380 & 380 & 380 & 380 & فولت & جها الثنيار المتردد \\
\hline $60 / 50-0$ & $60 / 50-0$ & $60 / 50-0$ & $60 / 50-0$ & $60 / 50-0$ & $60 / 50-0$ & $60 / 50-0$ & هرتز & Frequency التزردد \\
\hline 3 & 3 & 3 & 3 & 3 & 3 & 3 & & عدد الفازات \\
\hline 141 & 141 & 71 & 71 & 11 & 11 & 15 & امبير | امبير & Rated اقصي تيار \\
\hline & & & & & & & & تصميم الألو اح الثمسية \\
\hline الكمية & الكمية & الكمية & الكمية & الكمية & الكمية - الكمية & الكمية - الكمية & القياسة & البند البن ا \\
\hline 275 & 275 & 275 & 275 & 275 & 275 & 275 & وات & قلورة اللوح الثمسي \\
\hline 20 & 20 & 10 & 10 & 2 & 2 & 2 & مصفوفة & عدد مصفو فات الألو اح \\
\hline 18 & 18 & 18 & 18 & 14 & 14 & 18 & الوح & مصفو الألو اح في كل \\
\hline 4950 & 4950 & 4950 & 4950 & 3850 & 3850 & 4950 & ورات & قدرة المصفوفة الواحدة: \\
\hline 360 & 360 & 180 & 180 & 28 & 28 & 36 & لوح & الثمسيةية عدد الألو اح \\
\hline 99 & 99 & 49.5 & 49.5 & 7.7 & 7.7 & 9.9 & كوات & الشمسية قدرة الألو اح \\
\hline${ }^{\circ} 180$ & ${ }^{\circ} 180$ & ${ }^{\circ} 180$ & ${ }^{\circ} 180$ & ${ }^{\circ} 180$ & ${ }^{\circ} 180$ & ${ }^{\circ} 180$ & 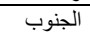 & توجية الألو اح الشمسية \\
\hline${ }^{\circ} 24$ & ${ }^{\circ} 24$ & ${ }^{\circ} 24$ & ${ }^{\circ} 24$ & ${ }^{\circ} 24$ & ${ }^{\circ} 24$ & ${ }^{\circ} 24$ & المنتوية & زاوية ميل الألّواح \\
\hline
\end{tabular}

المصدر :حسبت عن طريق برنامج طلمبات الطاقة الثمسية على حسب الاحتياج المائى للمحاصيل

الطريقتين السابقتين ، اما طريقة الري بالرش و التتقيط متساوية قدرة الطلمبة لها بسبب الاسباب المذكورة سابقا .اما مواصفات محطة الطاقة الثمسية للفئة الحيازية الثانية

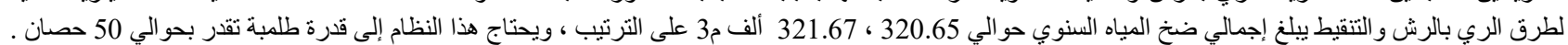

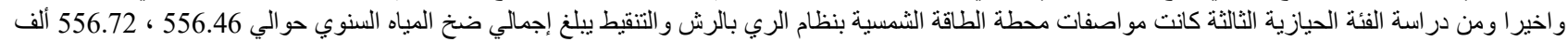

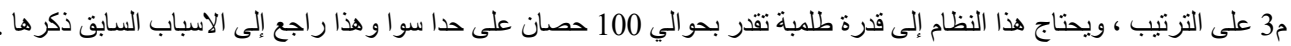

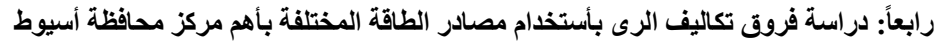

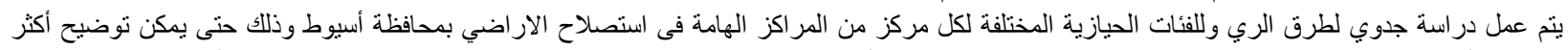

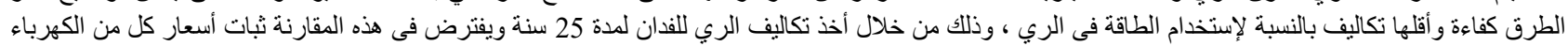

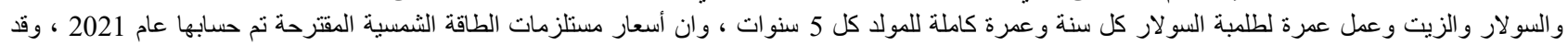
أسفرت النتائج لكل مركز بمايلي : 


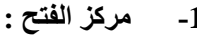

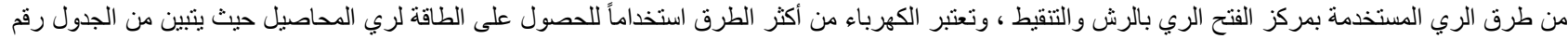

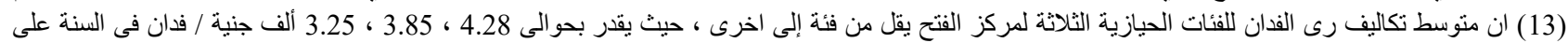

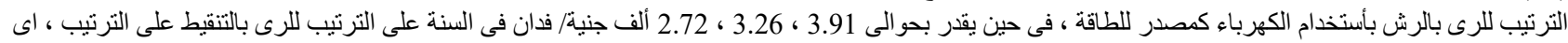

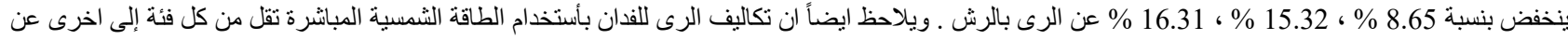

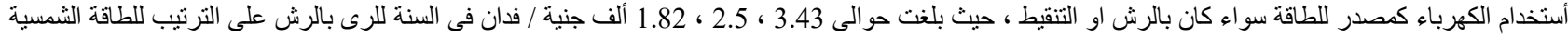

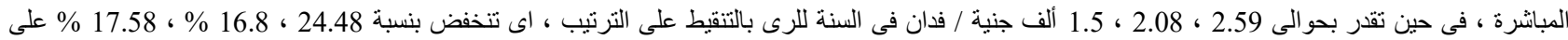

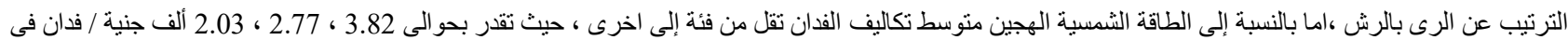

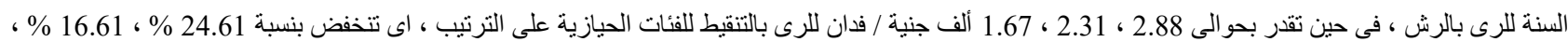

17.74 \% عن الرى بالرش على الترتيب ، و هذا يتمشى مع زيادة عو ائد السعة فى المساحات الكبيرة ويتمشى مع النظرية الاقتصادية .

جدول رقم (13): مقارنة دراسة الجدوي للري للفئات الحيازية الثلاثة بأستخدام طرق الطاقة المختلفة (الف جنية) للاراضى المستصلحة المزروعة بمركز الفتح خلال عام

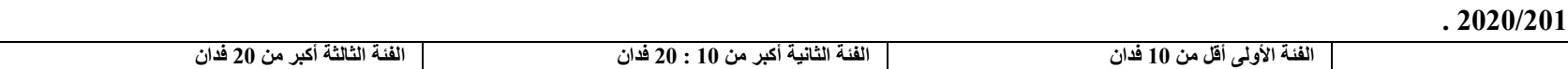

\begin{tabular}{|c|c|c|c|c|c|c|c|c|c|c|c|c|}
\hline \multicolumn{4}{|c|}{ الفئة الثالثة أكبر من 20 فدان } & \multicolumn{4}{|c|}{ الفئة الثانية أكبر من 10 : 20 فدان } & \multicolumn{4}{|c|}{ الفئة الأولى أقل من 10 فدان } & \multirow[b]{3}{*}{ البند / سنوات التشغيل } \\
\hline \multicolumn{2}{|c|}{ الري بالتنقيط } & \multicolumn{2}{|c|}{ 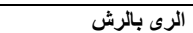 } & \multicolumn{2}{|c|}{ الري بالتتقيط } & \multicolumn{2}{|r|}{ الرى بالرش - الر } & \multicolumn{2}{|c|}{ الري بالتنقيط } & \multicolumn{2}{|c|}{ الرى بالرش - الر } & \\
\hline بالطاقة & بالكهرياء & الشمسية & بالكهرياء & بالطاقة & بالكهرباء & الشالطاقة & بالكهرباء & بالطاقة & بالكهرياء & الثباقية & بالكهرياء & \\
\hline \multicolumn{4}{|r|}{22} & \multicolumn{4}{|r|}{16} & \multicolumn{4}{|r|}{8} & متوسط العينة بالمركز (فدان) \\
\hline \multicolumn{2}{|c|}{120} & \multicolumn{2}{|r|}{150} & \multicolumn{2}{|r|}{120} & \multicolumn{2}{|r|}{150} & \multicolumn{2}{|r|}{75} & \multicolumn{2}{|r|}{100} & قدرة طلمبة الغاطس (حصان) \\
\hline 118.8 & & 144 & & 118.8 & & 143.6 & & 74.3 & & 99 & & الالو اح الثشسية (ك.وات) \\
\hline 531 & & 644 & & 534.6 & & 646.2 & & 334 & & 445.5 & & تُمن الالواح الثمسية \\
\hline 117 & & 148 & & 117 & & 140 & & 74 & & 98 & & الثمسنة الحوامل لتثبيت الالواح \\
\hline 85 & & 100 & & 85 & & 100 & & 50 & & 65 & & تُ تمن الانفرتر \\
\hline 165 & & 195 & & 165 & & 195 & & 95 & & 130 & & تُمن الانفرتر (الهجين) \\
\hline 11 & & 11 & & 11 & & 11 & & 10 & & 10 & & ثمن الاسلاك ولوحة التجميع \\
\hline 29.7 & & 35.9 & & 29.7 & & 35.9 & & 18.6 & & 24.75 & & تكاليف تصميم الالواح و العمالة \\
\hline 773.7 & & 938 & & 777.3 & & 933.1 & & 487 & & 643.3 & & 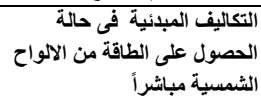 \\
\hline 11 & & 11 & & 11 & & 11 & & 11 & & 11 & & والثنيكة العداد التبادلي بين الالواح \\
\hline 864.7 & & 1044 & & 868.3 & & 1039 & & 543 & & 719.3 & & 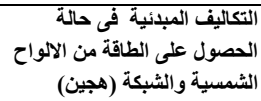 \\
\hline- & 62.5 & & 68.6 & & 54.4 & & 59.2 & & 30 & & 32 & تكاليف السنة الأولي \\
\hline- & 62.5 & & 68.6 & & 54.4 & & 59.2 & & 30 & & 32 & تكاليف السنة الثانية \\
\hline- & 62.5 & & 68.6 & & 54.4 & & 59.2 & & 30 & & 32 & تكاليف السنة الثالثة \\
\hline- & 62.5 & & 68.6 & & 54.4 & & 59.2 & & 30 & & 33 & تكاليف السنة الرابعة \\
\hline 4 & 62.5 & 5 & 68.6 & 4 & 54.4 & 5 & 59.2 & 2 & 30 & 3 & 33 & تكاليف السنة الخامسة \\
\hline- & 62.5 & & 68.6 & & 54.4 & & 59.2 & & 30 & & 33 & تكاليف السنة السادسة \\
\hline- & 62.5 & & 68.6 & & 54.4 & & 59.2 & & 30 & & 33 & تكاليف السنة السابعة \\
\hline- & 62.5 & & 68.6 & & 54.4 & & 59.2 & & 30 & & 33 & تكاليف السنة الثامنة \\
\hline- & 62.5 & & 68.6 & & 54.4 & & 59.2 & & 30 & & 33 & تكاليف السنة التاسعة \\
\hline 4 & 62.5 & 5 & 68.6 & 4 & 54.4 & 5 & 59.2 & 2 & 30 & 3 & 33 & تكاليف السنة العاثرة \\
\hline- & 62.5 & & 68.6 & & 54.4 & & 59.2 & & 30 & & 33 & تكاليف اللنةة الحادية عشر \\
\hline- & 62.5 & & 68.6 & & 54.4 & & 59.2 & & 30 & & 33 & تكاليف السنة الثانية عشر \\
\hline- & 62.5 & & 68.6 & & 54.4 & & 59.2 & & 30 & & 33 & تكاليف السنة الثالثة عشر \\
\hline- & 62.5 & & 68.6 & & 54.4 & & 59.2 & & 30 & & 33 & تكاليف السنة الرابعة عشر \\
\hline 4 & 62.5 & 5 & 68.6 & 4 & 54.4 & 5 & 59.2 & 2 & 30 & 3 & 33 & تكاليف السنة الخامسة عشر \\
\hline- & 62.5 & & 68.6 & & 54.4 & & 59.2 & & 30 & & 33 & تكاليف السنة السادسة عشر \\
\hline- & 62.5 & & 68.6 & & 54.4 & & 59.2 & & 30 & & 33 & تكاليف السنة السابعة عشر \\
\hline- & 62.5 & & 68.6 & & 54.4 & & 59.2 & & 30 & & 33 & تكاليف السنة الثامنة عشر \\
\hline- & 62.5 & & 68.6 & & 54.4 & & 59.2 & & 30 & & 33 & تكاليف السنة التاسعة عثر \\
\hline 4 & 62.5 & 5 & 68.6 & 4 & 54.4 & 5 & 59.2 & 2 & 30 & 3 & 33 & تكاليف السنة العشرون \\
\hline- & 62.5 & & 68.6 & & 54.4 & & 59.2 & & 30 & & 33 & تكاليف السنة الحادية والعشرون \\
\hline- & 62.5 & & 68.6 & & 54.4 & & 59.2 & & 30 & & 33 & تكاليف السنة الثانية والعشرون \\
\hline- & 62.5 & & 68.6 & & 54.4 & & 59.2 & & 30 & & 33 & تكاليف السنة الثالثة والعشرون \\
\hline & & & 68.6 & & & & 59.2 & & 30 & & 33 & تكاليف السنة الرابعة \\
\hline- & & 5 & 68.6 & 4 & & 5 & 59.2 & 2 & 30 & 3 & 33 & تكاليف السنة الخامسة \\
\hline 789.7 & 1437.0 & 963 & 1716.0 & 797.3 & 1251 & 958.1 & 1480 & 497 & 750 & 658.3 & 822 & الاجمالي العام للتكاليف سواء \\
\hline 880.7 & & 1069 & & 888.3 & & 1064 & & 553 & & 734.3 & & الاجمالي العام لتكاليف الْظاقةَّة \\
\hline 1.50 & 2.72 & 1.82 & 3.25 & 2.08 & 3.26 & 2.50 & 3.85 & 2.59 & 3.91 & 3.43 & 4.28 & متوسط تكاليف الفدان للطاقة/ \\
\hline 1.67 & & 2.03 & & 2.31 & & 2.77 & & 2.88 & & 3.82 & & متوسط تكاليف الفدان للطاقة/ \\
\hline
\end{tabular}

المصدر :حسبت من استمارة الاستبيان ، و الجدول رقم (9. 
:

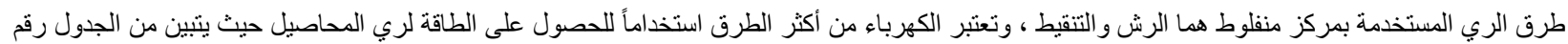

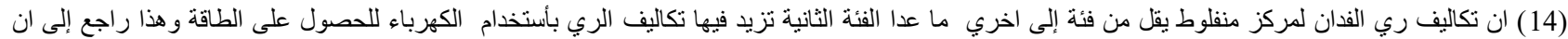

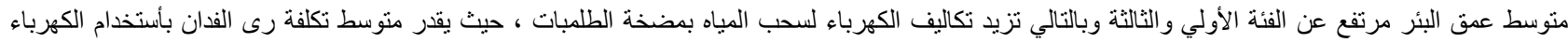

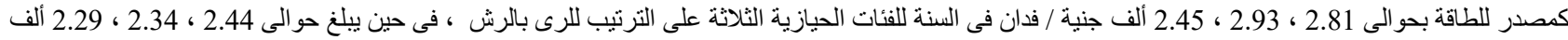

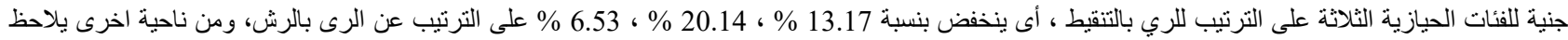
ايضاً ان تكاليف

جدول رقم (14): مقارنة دراسة الجدوي للري للفئات الحيازية الثلاثة بأستخدام طرق الطاقة المختلفة (الف جنية) للاراضى المستصلحة المزروعة بمركز منفلوط خلال

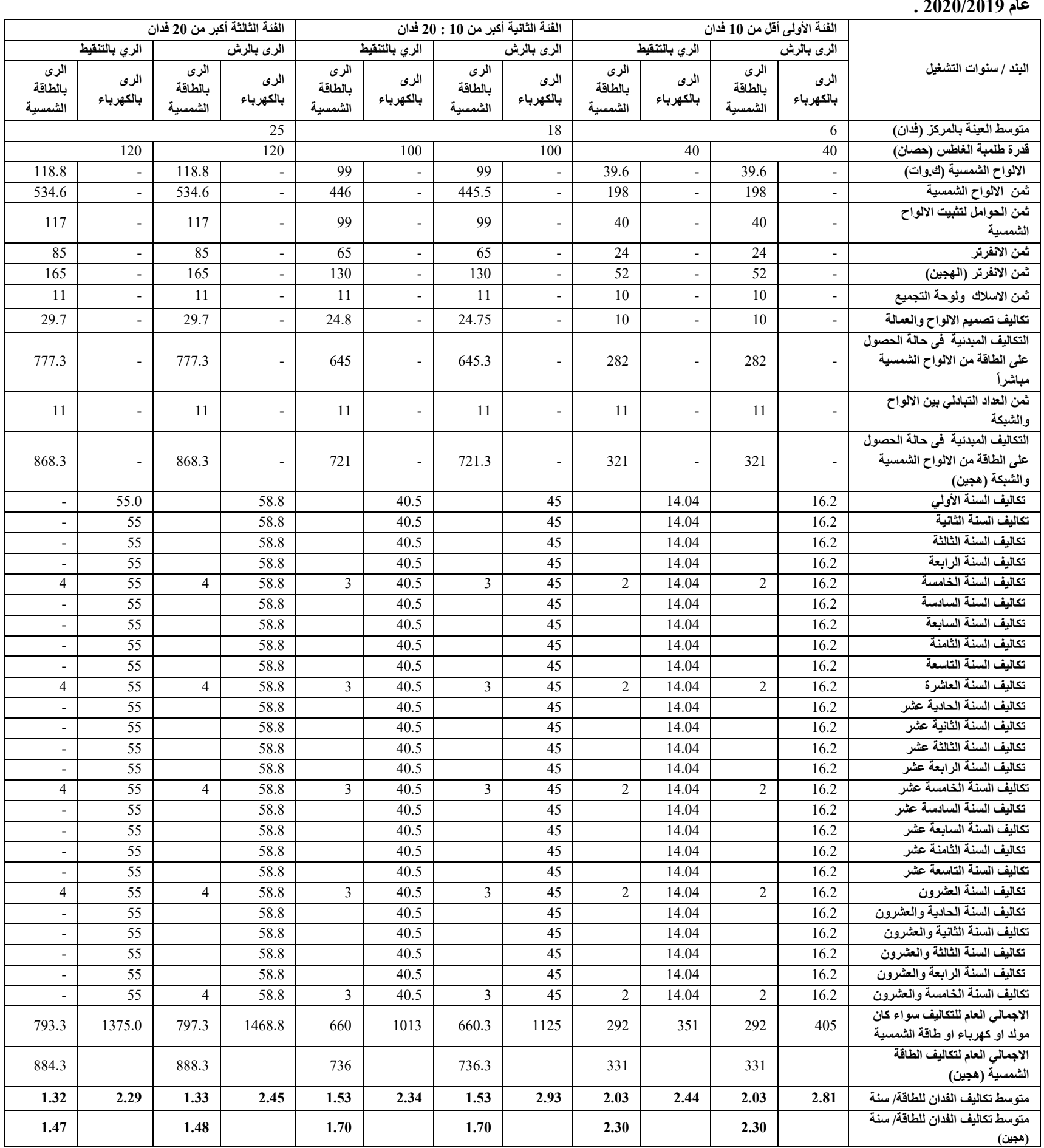




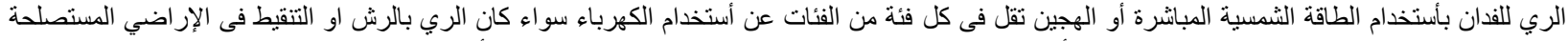

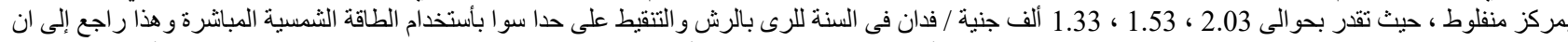

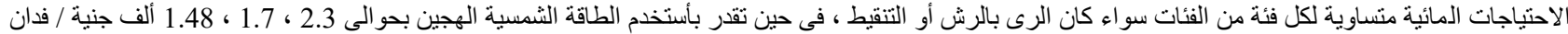

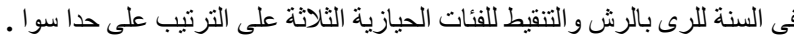

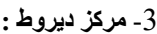

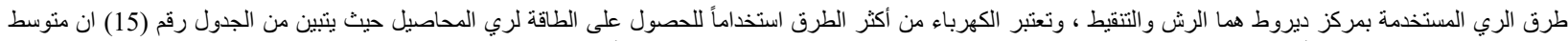

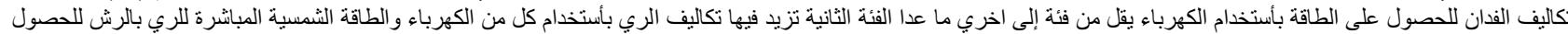

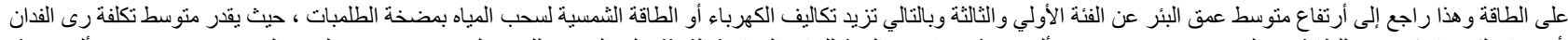

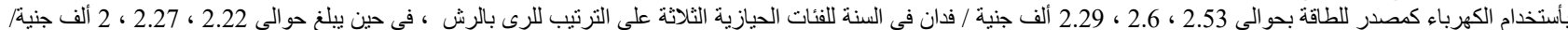

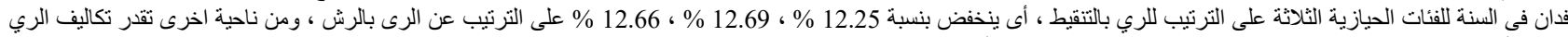

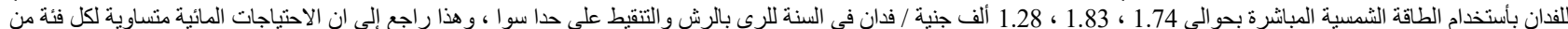

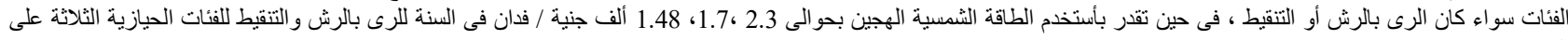

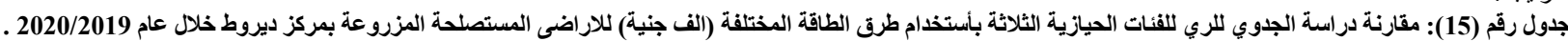

\begin{tabular}{|c|c|c|c|c|c|c|c|c|c|c|c|c|}
\hline \multicolumn{4}{|c|}{ الفئة الثالثة أكبر من 20 فدان } & \multicolumn{4}{|c|}{ الفئة الثانية أكبر من 10 : 20 فدان } & \multicolumn{4}{|c|}{ الفئة الأولى أقل من 10 فذان } & \multirow[b]{3}{*}{ البند / سنوات التثغيل } \\
\hline \multicolumn{2}{|c|}{ الري بالتنقيط } & \multicolumn{2}{|r|}{ 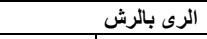 } & \multicolumn{2}{|c|}{ الري بالتنقيط } & \multicolumn{2}{|r|}{ 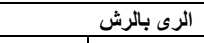 } & \multicolumn{2}{|c|}{ الري بالتنقيط } & \multicolumn{2}{|c|}{ الرى بالرش } & \\
\hline الشالطاقة & بالكهرياء & الرالطية & بالكهرياء & الثباقة & بالكهرياء & الشالطاقة & بالكهزياء & الشمسقة & بالكهرباء & الثالطاقة & بالكهرباء & \\
\hline & & & 26 & & & & 15 & & & & 7 & متوسط العينة بالمركز (فدان) \\
\hline & 120 & & 120 & & 75 & & 100 & & 40 & & 40 & قارة طلمبة الغاطس (حصان) \\
\hline 119 & & 119 & & 74.3 & & 99 & & 39.6 & & 39.6 & & الالواح الشمسية (ك.وات) \\
\hline 535 & & 535 & & 334 & & 446 & & 198 & & 198 & & ثمن الالواح الشمسية \\
\hline 117 & & 117 & & 74 & & 99 & & 40 & & 40 & & ثمن الحوامل لتثبيت الالواح الثمسية \\
\hline 85 & & 85 & & 50 & & 65 & & 24 & & 24 & & ثمن الانفرتر \\
\hline 165 & & 165 & & 95 & & 130 & & 52 & & 52 & & ثمن الانفرتر (الهجين) \\
\hline 11 & & 11 & & 10 & & 11 & & 10 & & 10 & & ثمن الاسلاك ولوحة التجميع \\
\hline 29.7 & & 29.7 & & 18.6 & & 24.8 & & 10 & & 10 & & تكاليف تصميم الالواح و العمالة \\
\hline 777 & & 777 & & 487 & & 645 & & 282 & & 282 & & 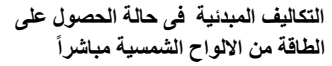 \\
\hline 11 & & 11 & & 11 & & 11 & & 11 & & 11 & & ثمن العداد التبادلي بين الالواح و الثبكة \\
\hline 868 & & 868 & & 543 & & 721 & & 321 & & 321 & & الطاقة من الالوائية الشمسية فالة الشصبكل على \\
\hline- & 49.92 & & 57.2 & & 32.7 & & 37.5 & & 14.91 & & 16.98 & تكاليف السنة الأولي \\
\hline- & 49.92 & & 57.2 & & 32.7 & & 37.5 & & 14.91 & & 16.98 & تكاليف السنة الثانية \\
\hline - & 49.92 & & 57.2 & & 32.7 & & 37.5 & & 14.91 & & 16.98 & تكاليف السنة الثالثة \\
\hline- & 49.92 & & 57.2 & & 32.7 & & 37.5 & & 14.91 & & 16.98 & تكاليف السنة الرابعة \\
\hline 4 & 49.92 & 4 & 57.2 & 2 & 32.7 & 3 & 37.5 & 2 & 14.91 & 2 & 16.98 & تكاليف السنة الخامسة \\
\hline- & 49.92 & & 57.2 & & 32.7 & & 37.5 & & 14.91 & & 16.98 & تكاليف السنة السادسة \\
\hline- & 49.92 & & 57.2 & & 32.7 & & 37.5 & & 14.91 & & 16.98 & تكاليف السنة السبابعة \\
\hline- & 49.92 & & 57.2 & & 32.7 & & 37.5 & & 14.91 & & 16.98 & تكاليف السنة الثامنة \\
\hline- & 49.92 & & 57.2 & & 32.7 & & 37.5 & & 14.91 & & 16.98 & تكاليف السنة التاسعة \\
\hline 4 & 49.92 & 4 & 57.2 & 2 & 32.7 & 3 & 37.5 & 2 & 14.91 & 2 & 16.98 & تكاليف السنة العاشرة \\
\hline- & 49.92 & & 57.2 & & 32.7 & & 37.5 & & 14.91 & & 16.98 & تكاليف السنة الحادية عشر \\
\hline- & 49.92 & & 57.2 & & 32.7 & & 37.5 & & 14.91 & & 16.98 & تكاليف السنة الثانية عشر \\
\hline- & 49.92 & & 57.2 & & 32.7 & & 37.5 & & 14.91 & & 16.98 & تكاليف السنة الثالثة عشر \\
\hline- & 49.92 & & 57.2 & & 32.7 & & 37.5 & & 14.91 & & 16.98 & تكاليف السنة الرابعة عشر \\
\hline 4 & 49.92 & 4 & 57.2 & 2 & 32.7 & 3 & 37.5 & 2 & 14.91 & 2 & 16.98 & تكاليف السنة الخامسة عشر \\
\hline- & 49.92 & & 57.2 & & 32.7 & & 37.5 & & 14.91 & & 16.98 & تكاليف السنة السادسة عشر \\
\hline- & 49.92 & & 57.2 & & 32.7 & & 37.5 & & 14.91 & & 16.98 & تكاليف السنة السابعة عشر \\
\hline- & 49.92 & & 57.2 & & 32.7 & & 37.5 & & 14.91 & & 16.98 & تكاليف السنة الثامنة عشر \\
\hline- & 49.92 & & 57.2 & & 32.7 & & 37.5 & & 14.91 & & 16.98 & تكاليف السنة التاسعة عشر \\
\hline 4 & 49.92 & 4 & 57.2 & 2 & 32.7 & 3 & 37.5 & 2 & 14.91 & 2 & 16.98 & تكاليف السنة العشرون \\
\hline- & 49.92 & & 57.2 & & 32.7 & & 37.5 & & 14.91 & & 16.98 & تكاليف السنة الحادية و العشرون \\
\hline- & 49.92 & & 57.2 & & 32.7 & & 37.5 & & 14.91 & & 16.98 & تكاليف السنة الثانية والعشرون \\
\hline- & 49.92 & & 57.2 & & 32.7 & & 37.5 & & 14.91 & & 16.98 & تكاليف السنة الثالثة و العشرون \\
\hline & 49.92 & & 57.2 & & 32.7 & & 37.5 & & 14.91 & & 16.98 & تكاليف السنة الرابعة والعشرون \\
\hline- & 49.92 & 4 & 57.2 & 2 & 32.7 & 3 & 37.5 & 2 & 14.91 & 2 & 16.98 & تكاليف السنة الخامسة والعُشرون \\
\hline 793 & 1248 & 797 & 1430 & 497 & 817.5 & 660 & 937.5 & 292 & 372.8 & 292 & 424.4 & كهرباء الو طاقة الثشمسية سواء كان مولا او \\
\hline 884 & & 888 & & 553 & & 736 & & 331 & & 331 & & الاجمالي العام لتكاليف الطاقة الثمسية \\
\hline 1.27 & 2.00 & 1.28 & 2.29 & 1.38 & 2.27 & 1.83 & 2.60 & 1.74 & 2.22 & 1.74 & 2.53 & متوسط تكاليف الفدان للطاقة/ سنة \\
\hline 1.42 & & 1.42 & & 1.54 & & 2.05 & & 1.97 & & 1.97 & & متوسط تكاليف الفدان للطاقة/ سنة \\
\hline
\end{tabular}

المصدر : حسبت من استمارة الاستبيان ، و الجدول رقم (11).

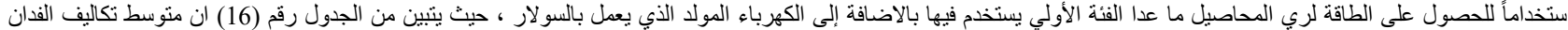


للحصول على الطاقة للري بالغمر يقدر بحو الي 7.7 ، 3.33 ، 0.78 ، 1.05 ألف جنية / فدان لكل من أستخدام المولد ، و الكهرباء ، والطاقة الثمسية المباشرة ، والطاقة الثمسية الهجين على

جدول رقم (16): مقارنة دراسة الجدوي للري للفنات الحيازية الثلاثة باستخدام طرق الطقة المخلفة (لف جنية) للاراضى المستصلحة المزروعة بمركز البارى خلال

\begin{tabular}{|c|c|c|c|c|c|c|c|c|c|}
\hline \multicolumn{9}{|c|}{ | الفئة الأولي أقلّ من 10 فدان } & \multirow[b]{3}{*}{ البنذ / سنوات التثشغيل } \\
\hline & \multicolumn{2}{|c|}{ الري بالتنقيط } & \multicolumn{3}{|c|}{ 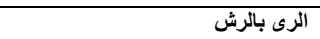 } & \multicolumn{3}{|c|}{ الرى بالغفر } & \\
\hline 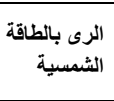 & 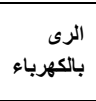 & 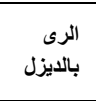 & الثالطاقة & 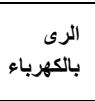 & 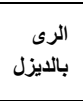 & الثمساقة & 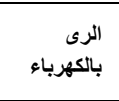 & بالديزل & \\
\hline \multicolumn{3}{|r|}{5} & \multicolumn{3}{|r|}{5} & \multicolumn{3}{|r|}{5} & متوسط العينة بالمركز (فدان) \\
\hline 7.5 & & & 7.5 & & & 10 & - & & قررة طلمبة الغاطس (حصان) \\
\hline 7.7 & & & 7.7 & & & 9.9 & - & & مولاد - الالواح الثمسية (ك.وات) \\
\hline 38.5 & & 30 & 38.5 & & 30 & 49.5 & - & 40 & ثمن المولد - الالواح الثُمسية \\
\hline 8 & & & 8 & & & 10 & - & & ثمن الحوامل لتثبيت الالواح الثشمسية \\
\hline 10 & & & 10 & & & 14 & - & & ثمن الانفرتر \\
\hline 30 & & & 30 & & & 36 & - & & ثمن الاتفرتر (الهجين) \\
\hline 6 & & & 6 & & & 7 & - & & ثمن الاسلاك ولوحة التجميع \\
\hline 2.4 & & & 2.4 & & & 3 & - & & تكاليف تصميم الالواح و العمالة \\
\hline 64.9 & & & 64.9 & & & 83.5 & - & & مباشراً التبا المبئية فى حالة الحصول على الطاقة من الالواح الثشسية \\
\hline 11 & & & 11 & & & 11 & - & & ثُمن العداد التبادلي بين الالواح و الثشبكة \\
\hline \multirow[t]{12}{*}{95.9} & & & 95.9 & & & 116.5 & - & & والثبكة (هجين) المبئة فى حالة الحصول على الطاقة من الالواح الثمسية \\
\hline & & 3.25 & & & 3.50 & & - & 3.75 & إجمالي السولار المستخدم (الف لتر/ سنة) \\
\hline & & 25.19 & & & 27.13 & & - & 29.06 & اجمالى ثمن السولار (الف جنية/ سنة) \\
\hline & & 0.08 & & & 0.09 & & - & 0.10 & اجمالي الزيت (الف لتر / سنة) \\
\hline & & 2.63 & & & 2.98 & & - & 3.50 & اجمالي ثمن الزيت (الف جنية / سنة) \\
\hline & & 27.81 & & & 30.10 & & - & 32.56 & إجمالي تكاليف ( السولار + الزيت) فى السنة \\
\hline & & 2 & & & 2 & & - & 2 & تكاليف عمرة طلمبة السولار فى السنة \\
\hline & & 5 & & & 5 & & & 5 & تكاليف عمرة المولد كل5سنوات \\
\hline & 11.75 & 29.81 & & 13.01 & 32.1 & & 16 & 34.56 & تكاليف السنة الأولي \\
\hline & 11.75 & 29.81 & & 13.01 & 32.1 & & 16 & 34.56 & تكاليف السنة الثانية \\
\hline & 11.75 & 29.81 & & 13.01 & 32.1 & & 16 & 34.56 & تكاليف السنة الثالثة \\
\hline & 11.75 & 29.81 & & 13.01 & 32.1 & & 16 & 34.56 & تكاليف السنة الرابعة \\
\hline \multirow[t]{5}{*}{1.5} & 11.75 & 34.81 & 1.5 & 13.01 & 37.1 & 2 & 16 & 39.56 & تكاليف السنة الخامسة \\
\hline & 11.75 & 29.81 & & 13.01 & 32.1 & & 16 & 34.56 & تكاليف السنة السادسة \\
\hline & 11.75 & 29.81 & & 13.01 & 32.1 & & 16 & 34.56 & تكاليف السنة السابعة \\
\hline & 11.75 & 29.81 & & 13.01 & 32.1 & & 16 & 34.56 & تكاليف السنة الثامنة \\
\hline & 11.75 & 29.81 & & 13.01 & 32.1 & & 16 & 34.56 & تكاليف السنة التاسعة \\
\hline \multirow[t]{5}{*}{1.5} & 11.75 & 34.81 & 1.5 & 13.01 & 37.1 & 2 & 16 & 39.56 & تكاليف السنة العاشرة \\
\hline & 11.75 & 29.81 & & 13.01 & 32.1 & & 16 & 34.56 & تكاليف السنة الحادية عشر \\
\hline & 11.75 & 29.81 & & 13.01 & 32.1 & & 16 & 34.56 & تكاليف السنة الثانية عثر \\
\hline & 11.75 & 29.81 & & 13.01 & 32.1 & & 16 & 34.56 & تكاليف السنة الثالثة عشر \\
\hline & 11.75 & 29.81 & & 13.01 & 32.1 & & 16 & 34.56 & تكاليف السنة الرابعة عشر \\
\hline \multirow[t]{5}{*}{1.5} & 11.75 & 34.81 & 1.5 & 13.01 & 37.1 & 2 & 16 & 39.56 & تكاليف السنة الخامسة عشر \\
\hline & 11.75 & 29.81 & & 13.01 & 32.1 & & 16 & 34.56 & تكاليف السنة السادسة عثر \\
\hline & 11.75 & 29.81 & & 13.01 & 32.1 & & 16 & 34.56 & تكاليف السنة السابعة عثر \\
\hline & 11.75 & 29.81 & & 13.01 & 32.1 & & 16 & 34.56 & تكاليف السنة الثامنة عثر \\
\hline & 11.75 & 29.81 & & 13.01 & 32.1 & & 16 & 34.56 & تكاليف السنة التاسعة عشر \\
\hline \multirow[t]{5}{*}{1.5} & 11.75 & 34.81 & 1.5 & 13.01 & 37.1 & 2 & 16 & 39.56 & تكاليف السنة العشرون \\
\hline & 11.75 & 29.81 & & 13.01 & 32.1 & & 16 & 34.56 & تكاليف السنة الحادية والعُرون \\
\hline & 11.75 & 29.81 & & 13.01 & 32.1 & & 16 & 34.56 & تكاليف السنة الثانية والعشرون \\
\hline & 11.75 & 29.81 & & 13.01 & 32.1 & & 16 & 34.56 & تكاليف السنة الثالثة والعشرون \\
\hline & 11.75 & 29.81 & & 13.01 & 32.1 & & 16 & 34.56 & تكاليف السنة الرابعة والعشرون \\
\hline 1.5 & 11.75 & 29.81 & 1.5 & 13.01 & 32.1 & 2 & 16 & 34.56 & تكاليف السنة الخامسة والعشرون \\
\hline 72.4 & 293.75 & 795.31 & 72.4 & 325.25 & 852.5 & 93.5 & 400 & 924.06 & الاجمالي العام للتكاليف سواء كان مولا او كهرباء او طاقة الثمسبة \\
\hline 103.4 & - & & 103.4 & - & & 126.5 & - & & الاجمالي العام لتكاليف الطاقة الثمسية (هجين) \\
\hline 0.60 & 2.45 & 6.63 & 0.60 & 2.71 & 7.10 & 0.78 & 3.33 & 7.70 & متوسط تكاليف الفذان للطاقة/ سنة \\
\hline 0.86 & - & & 0.86 & - & & 1.05 & 3.33 & & متوسط تكاليف الفدان للطاقة/ سنة (هجين) \\
\hline
\end{tabular}

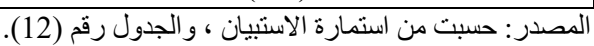


تابع الجدول رقم (16):مقارنة دراسة الجدوي للري للفئات الحيازية الثلاثة بأستخدام طرق الطاقة المختلفة (الف جنية) للاراضى المستصلحة والمزروعة بمركز البدارى

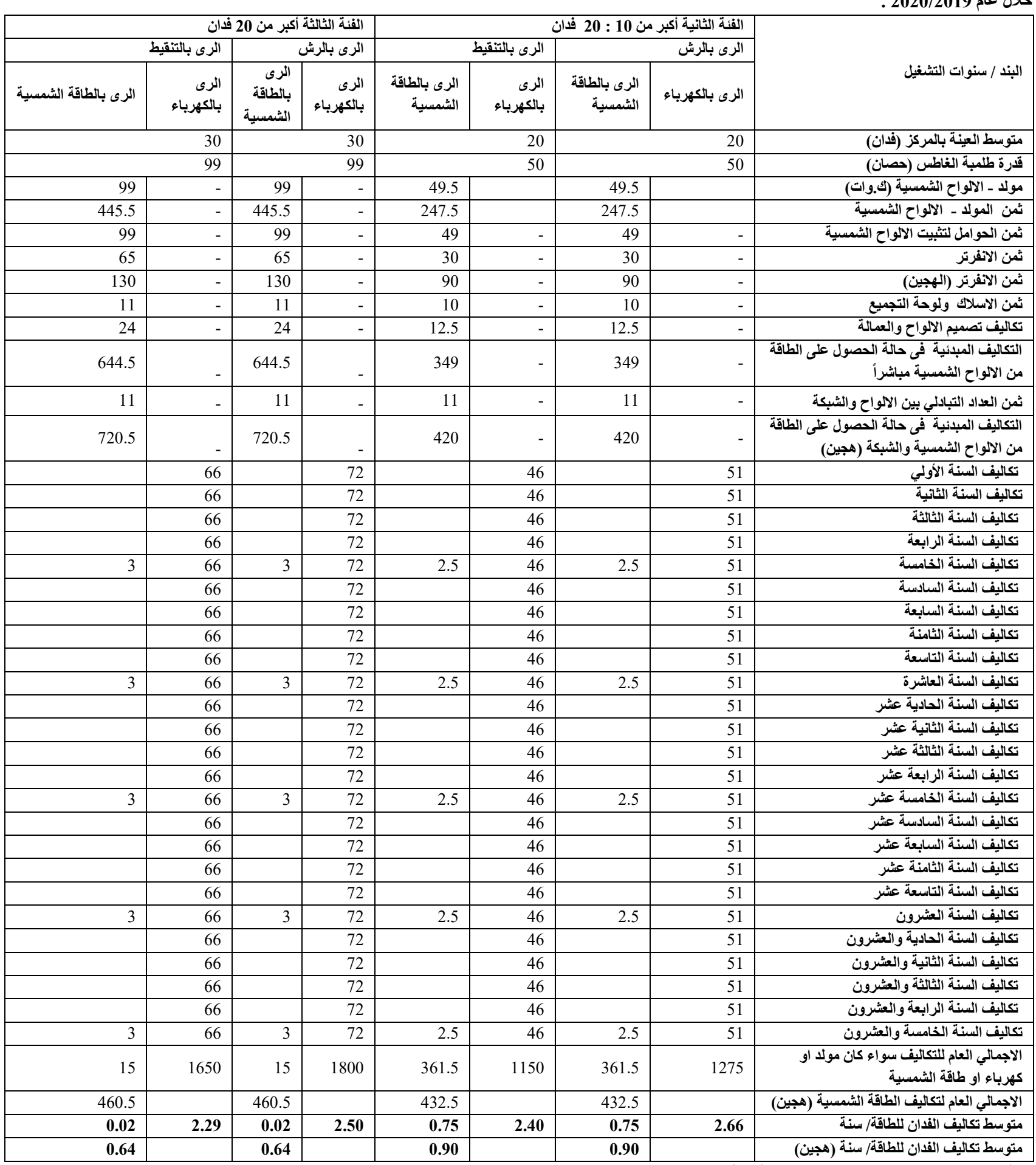

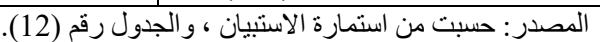

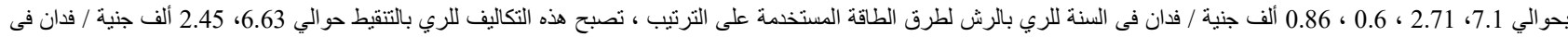

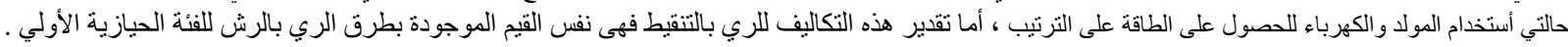

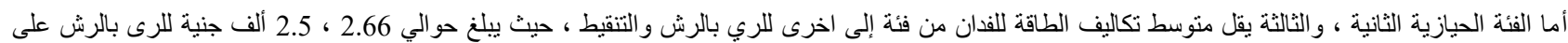

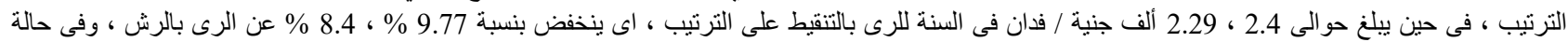

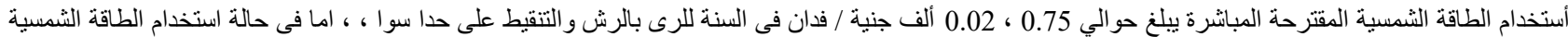

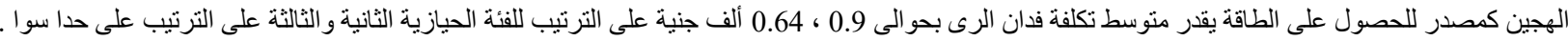

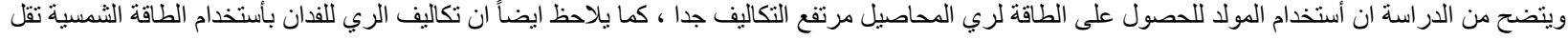

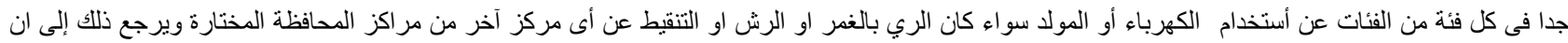
منوسط عمق البئر منخفض من الفنار عنة بباقي المر اكز 
تحليل التباين لأثر أنظمة الطاقة والفئات الحيازية المختلفة على تكاليف الري للفدان للمحاصيل المزروعة بالاراضي المستصلحة بمحافظة أسيوط :

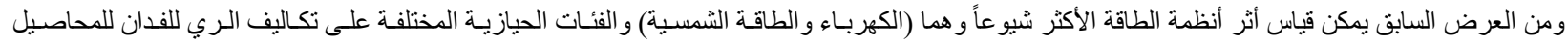

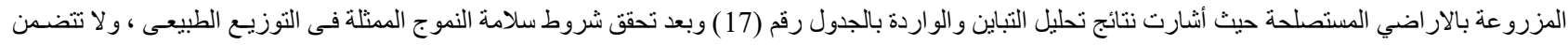

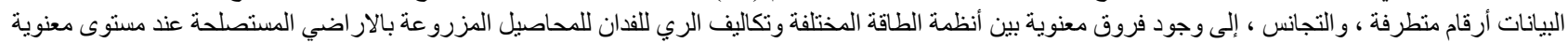

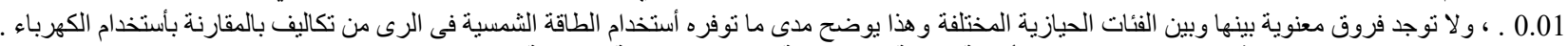

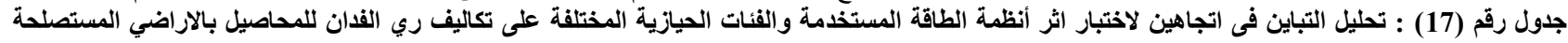

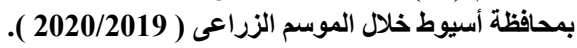

\begin{tabular}{|c|c|c|c|c|}
\hline قيمة ف المحسوبة & متوسط مربع الأحررافات & درجات الحرية & مجموع مربعات الأتحرافات & مصدر الاختلاف \\
\hline$* 19.288$ & 10.667 & 1 & 10.667 & بين أنظمة الطاقة المستخدمة \\
\hline \multirow[t]{3}{*}{1.616} & 0.894 & 2 & 1.787 & بين الفئات الحيازية المختلفة \\
\hline & 0.553 & 20 & 11.06 & الخطأ \\
\hline & & 23 & 23.514 & المجموع \\
\hline
\end{tabular}

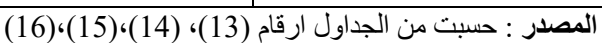

خامساً : الفروق بين تكاليف الري الراجعة لإستخدام طرق الطامة الطاقة المختلفة وكلا من الطاقة الثمسية المباشرة والهجين بأهم مراكز محافظة أسيوط فى الاراضي الزراعية المستصلحة : الفروف : -

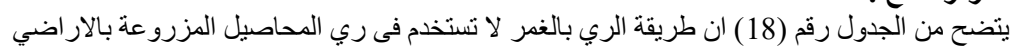

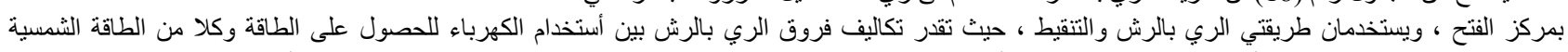

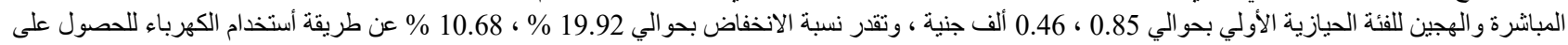

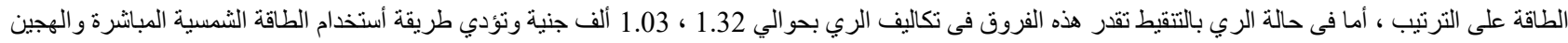

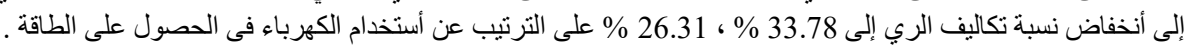

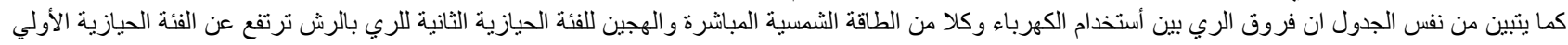

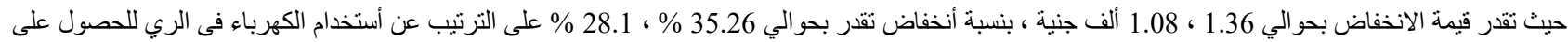

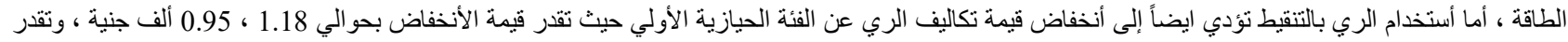

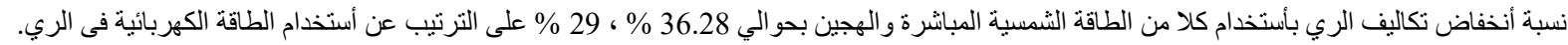

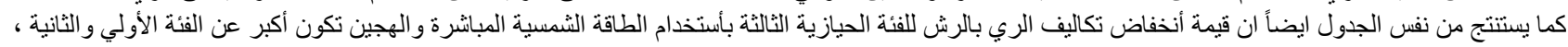

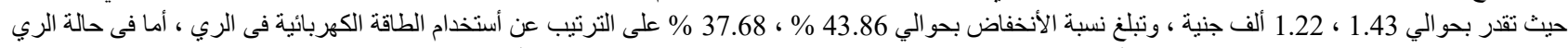

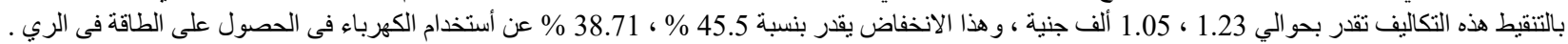

: 1

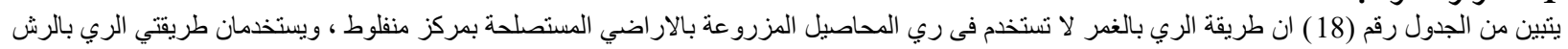

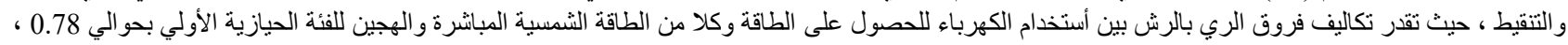

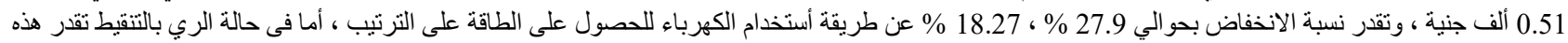

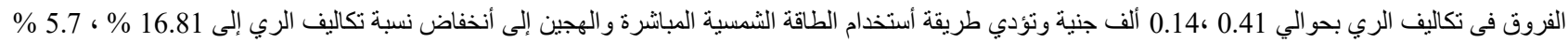

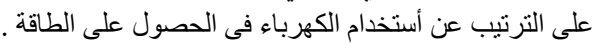

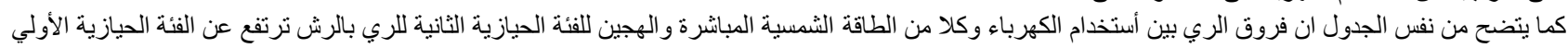

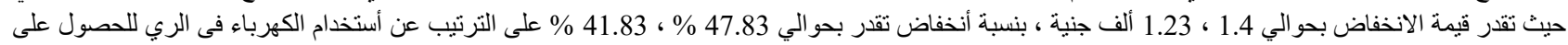

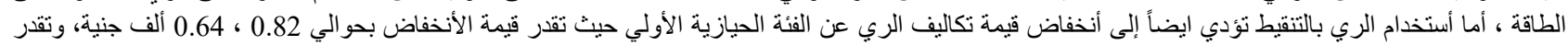

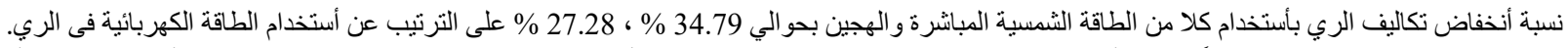

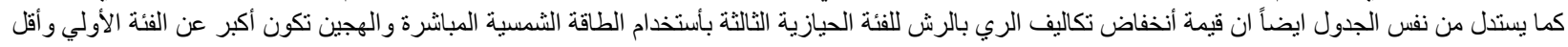

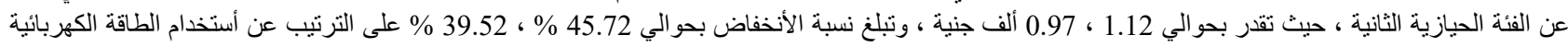

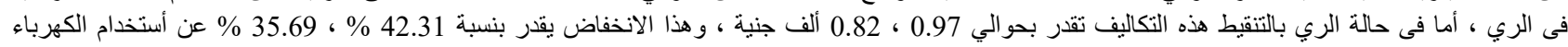
للحصول على الطاقة فى الري في في الري

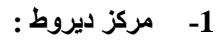

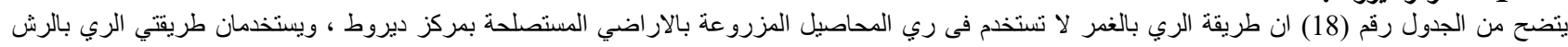

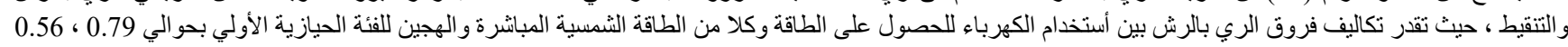

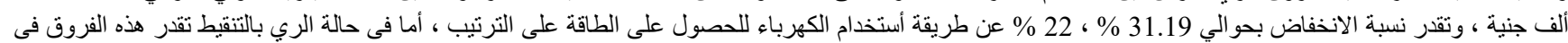

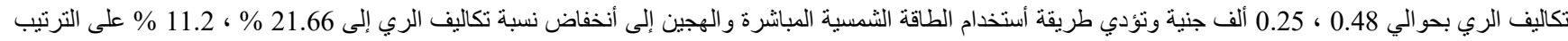

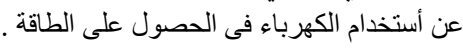

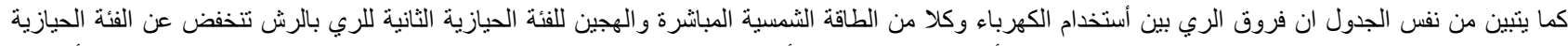

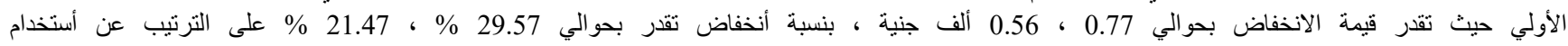




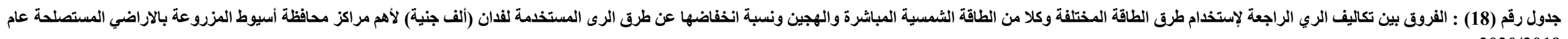

.2020/2019

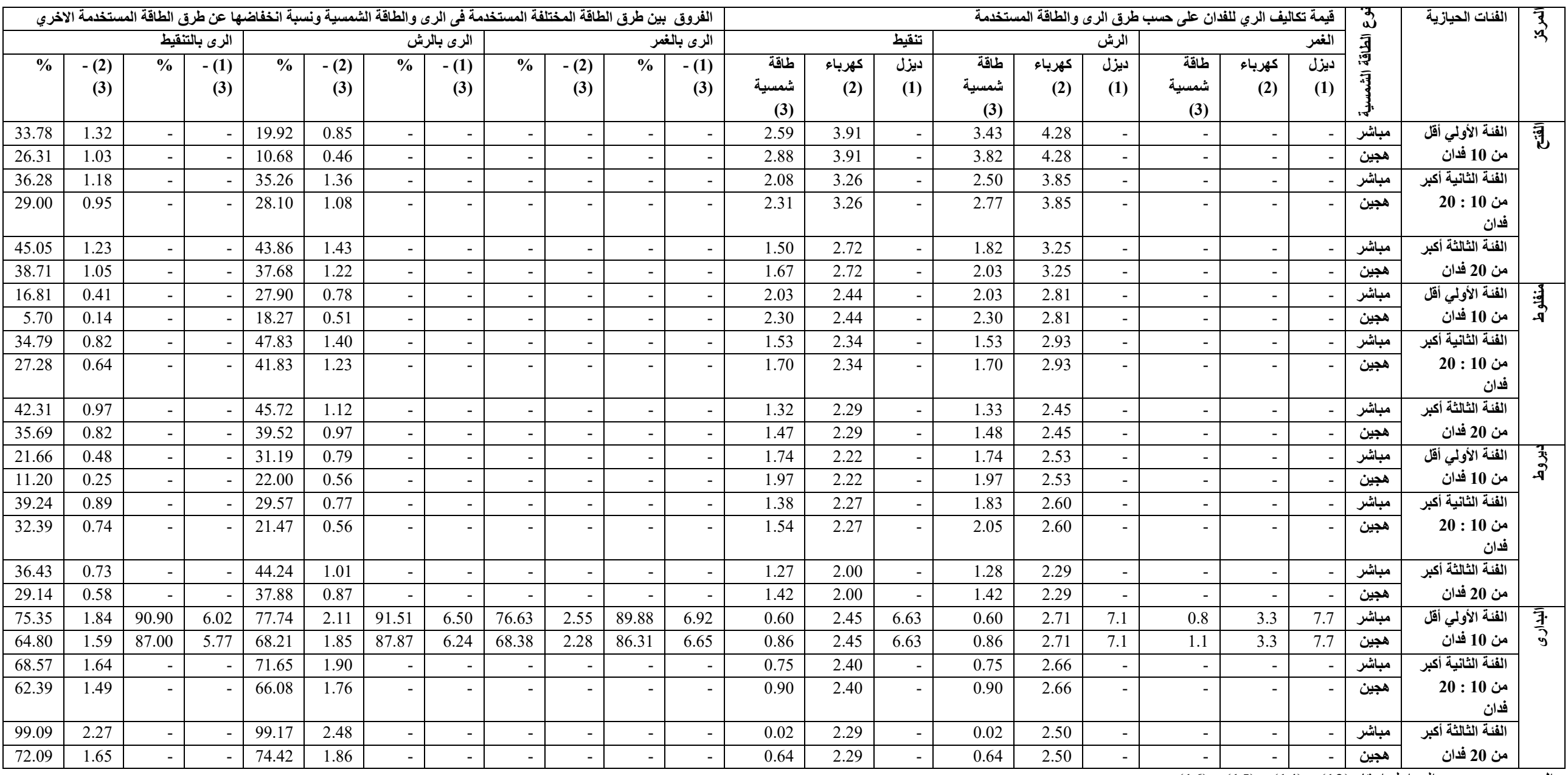

المصدر:حسبت من الجداول ارقام (13) ، (14) ، (15) ، (15) (15) 
الكهرباء فى الري للحصول على الطاقة، أما أستخدام الري بالتتقيط تؤدي ايضاً إلى أنخفاض أكبر لقيمة تكاليف الري عن الفئة الحيازية الأولي حيث تقدر قيمة الأنخفاض

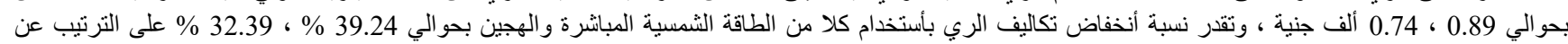
أستخدام الطاقة الكهربائية فى الري.

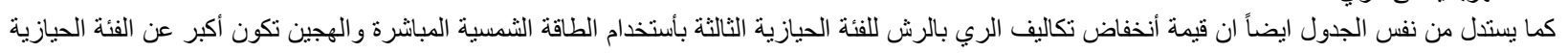

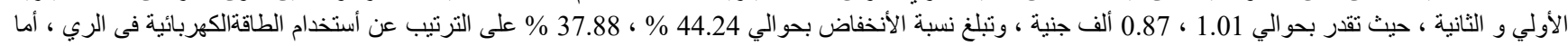

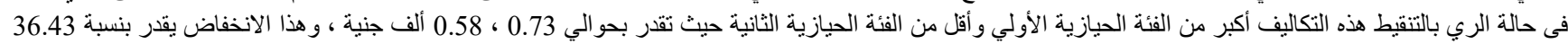

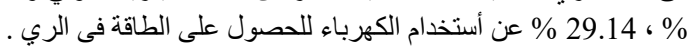
2-2 - مركز البداري :

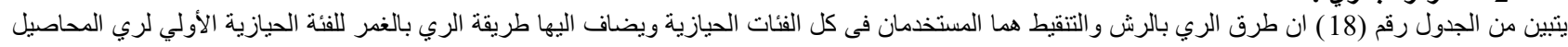

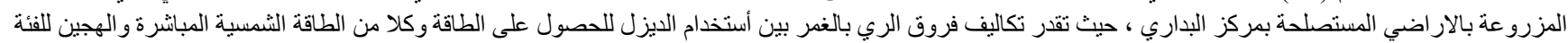

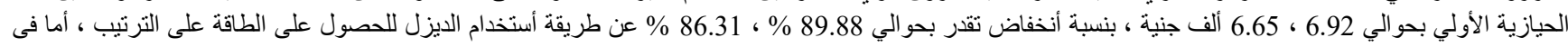

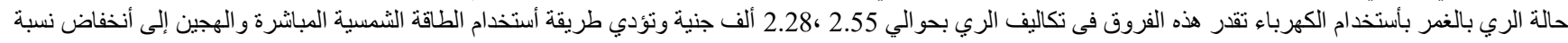

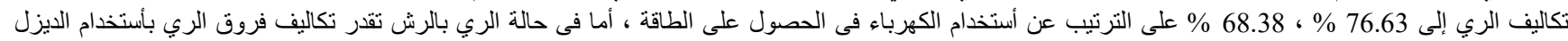

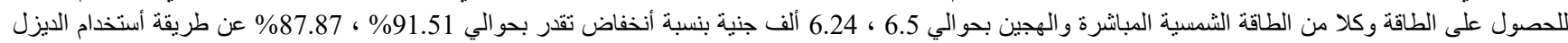

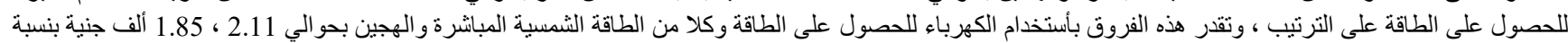

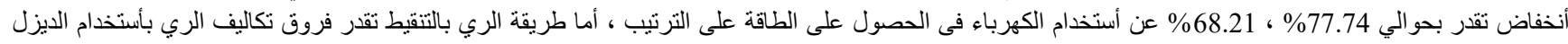

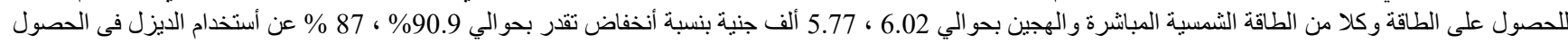

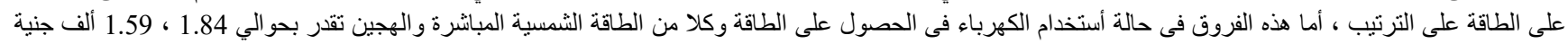

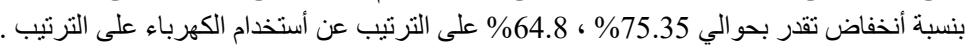

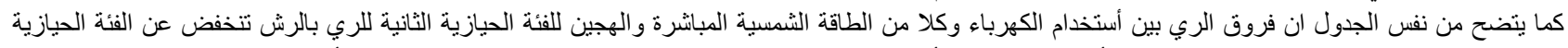

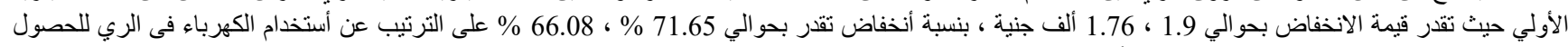

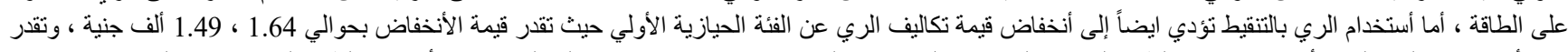

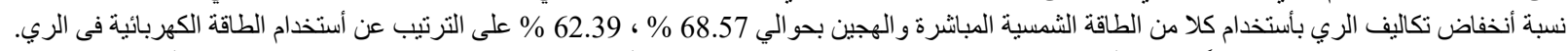

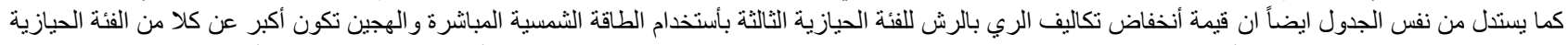

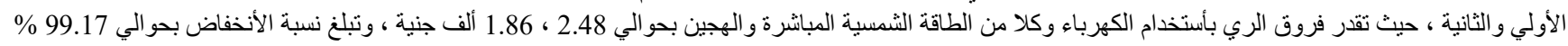

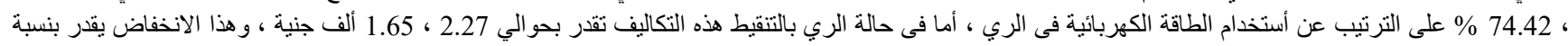

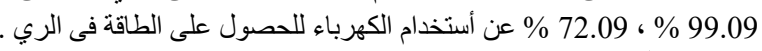

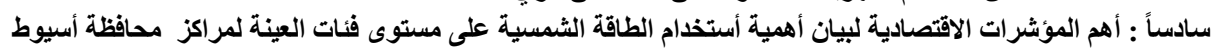

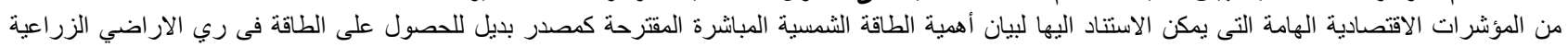

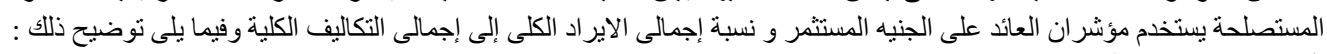

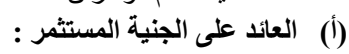

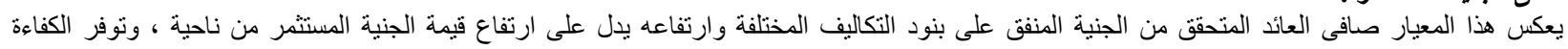

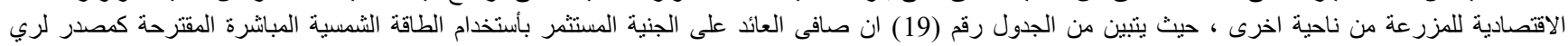

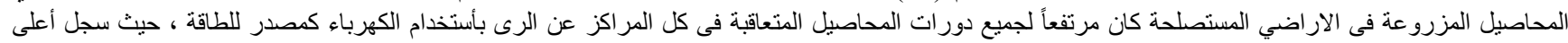

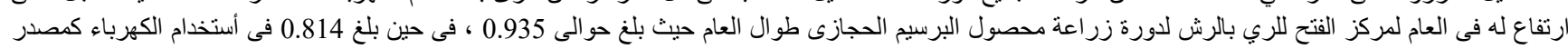

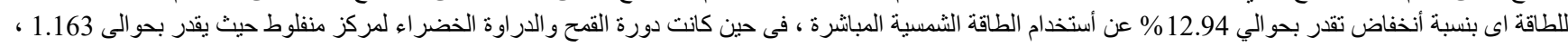

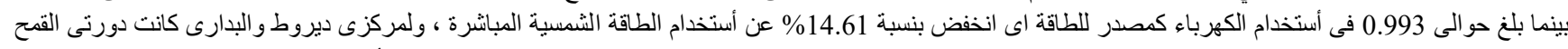

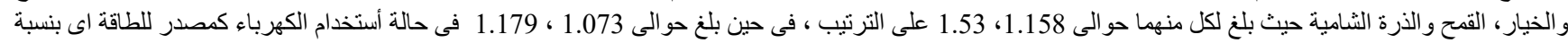

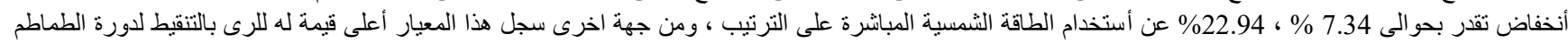

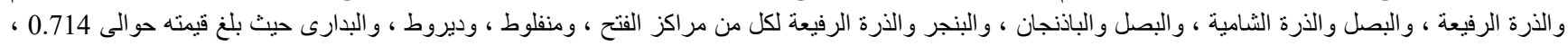

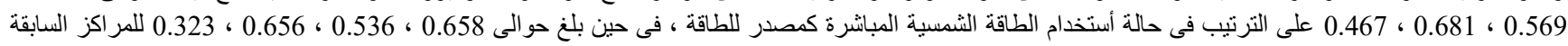

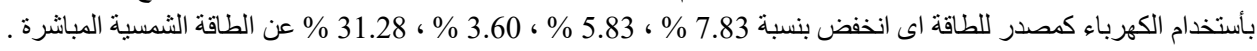

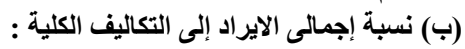

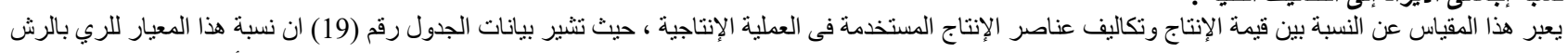

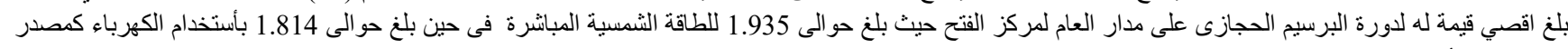

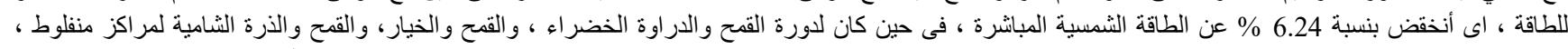

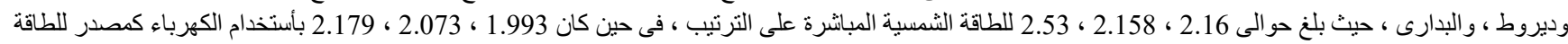

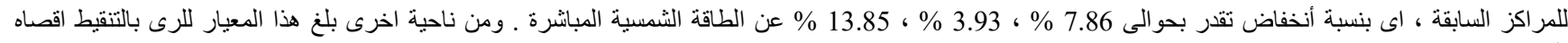

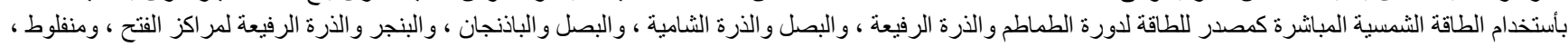

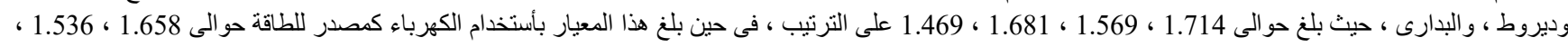

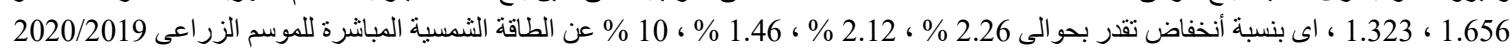

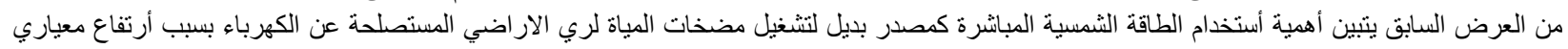

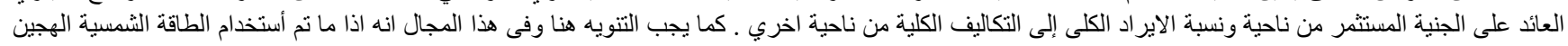

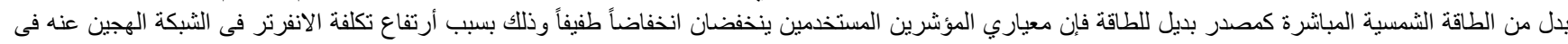
شبكة الطاقة الثمسية المباشرة . 
الفدول رقم (19): بعض المؤشرات الاقتصادية الهامة لتعاقب أهم المحاصيل المزروعة بالاراضي المستصلحة على مستوى الفئات ومراكز العينة على حسب أهم كل من طرق الطاقة المستخدمة وانظمة الرى المختلفة خلال الموسم الزراعى 2020/2019.

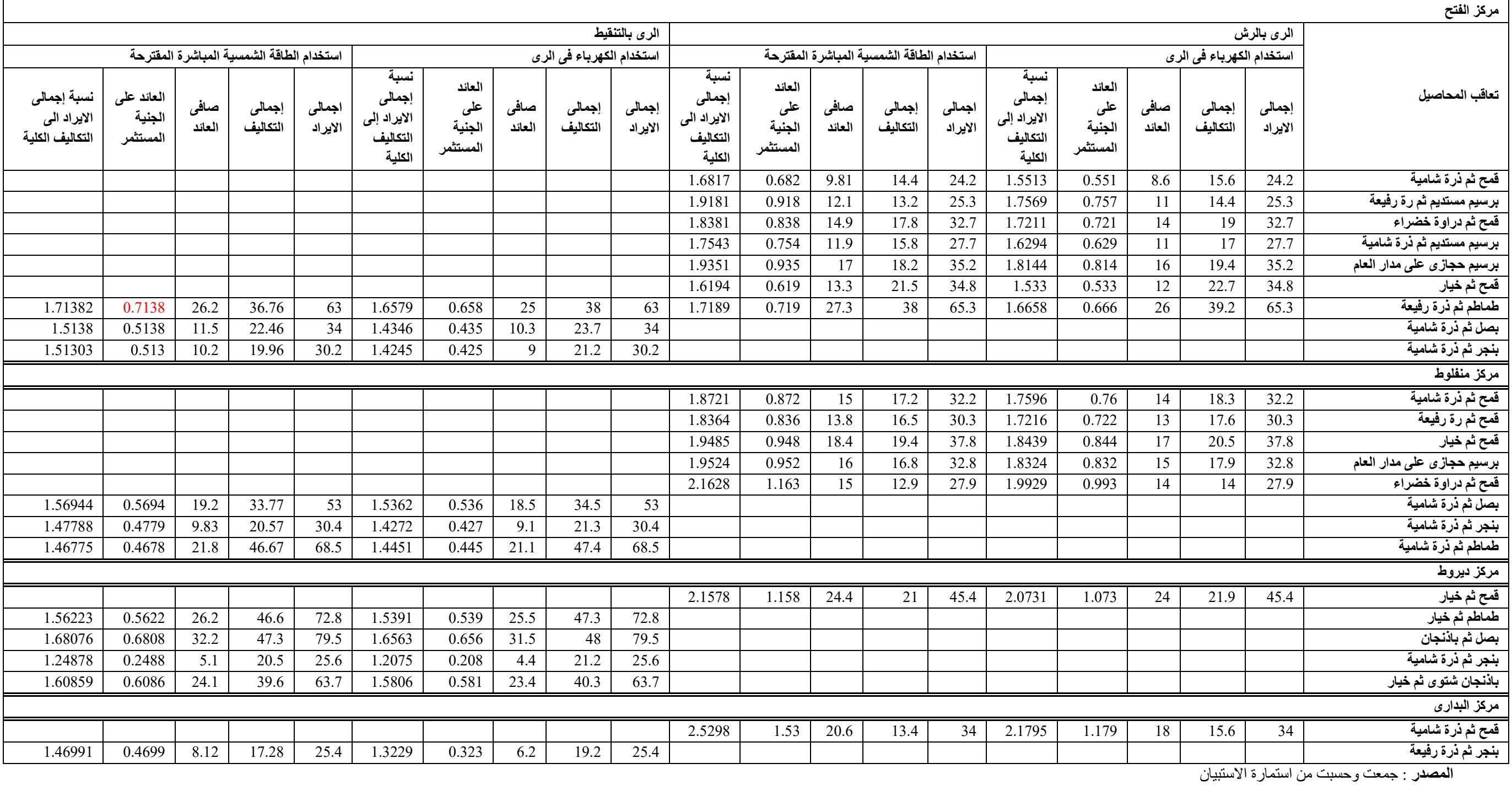


دراسة المميزات والعيوب لاستخدام مضخات المياة التي تعمل بالطاقة الثمسية والكهرباء والديزل

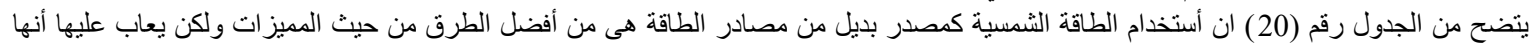

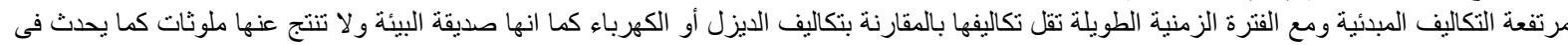

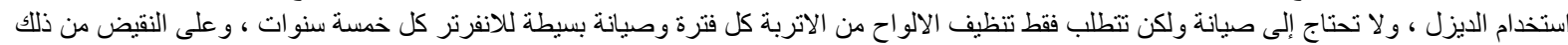

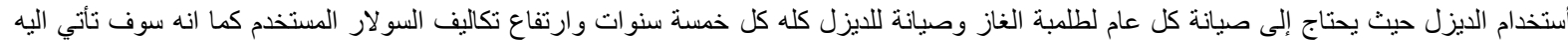

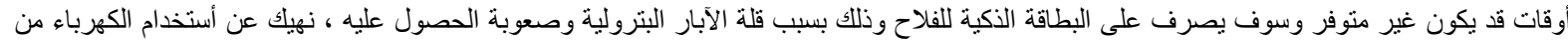

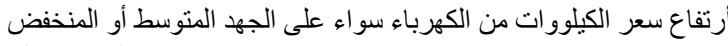

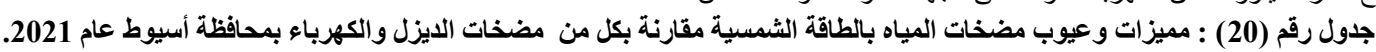

\begin{tabular}{|c|c|c|c|}
\hline مضخات الطاقة الثمسية & مضخات الكهرباء & مضخات الديزل & الصفة المميزة \\
\hline تتطلب مساحة كبيرة ومفتوحة & تتطلب مساحة صغيرة & تتطلب مساحة صغيرة & مساحة التركيب \\
\hline التكلفة مرتفعة & التكلفة مرتفعة نوعاً ما & التكلفة منخفضة & التكلفة التأسيسية \\
\hline لا تتطلب تكلفة تشغيل & التكلفة مرتفعة & التكلفة مرتفعة جدا & التكلفة التشغيلية \\
\hline تشغيل محدود بساعات سطوع & تشغيل متاح فى جميع الأوقات & تشغيل متاح فى جميع الأوقات & وقت التشغيل \\
\hline تحتاج خبر ات فنية خاصة & تركيبها بسيط & تركيبها بسيط نو عا ما & خبرة التركيب \\
\hline لا تحتاج مر اقبة دائمة & تحتاج متابعة طو ال الوقت & تحتاج متابعة طو ال الوقت & خبرة التشغيل \\
\hline نظيفة بيئيا & ليست ضارة على البيئة و الصحة & ضارة على البيئة و الصحة & التأثثر البيئي \\
\hline كفاءة مستدامة و عمر ها طويل & تقل كفاءتها مع الزمن نو عاو عمر ها متوسط & تقل كفاءتها مع الزمن و عمر ها قصير & العمر الحياتي \\
\hline يخزن طاقة ويجهزها عندما & يستهللك كهرباء وينتج طاقة ثابتة لتشغيل المضخة & يستهلك وقود وينتج طاقة ثابتة بغض النظر عن & 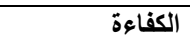 \\
\hline نادر ا ما تتطلب صبانة & تحتاج لصيانة بسيطة & تحتاج صيانة وتغيير قطع دوريا & الصياتة \\
\hline تكاليفها قليلة على المدى الزمني & تكاليفها متوسطة على المدى الزمني الطويل & تكاليفها مرتفعة على المدي الزمنى الطويل & التكلفة التراكمية \\
\hline 25-20 سنة & 12-10 سنة & 10-8 سنو ات & العمر الافتراضي \\
\hline
\end{tabular}

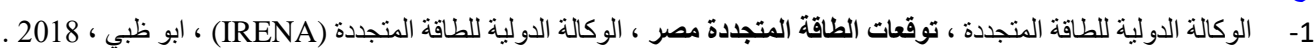

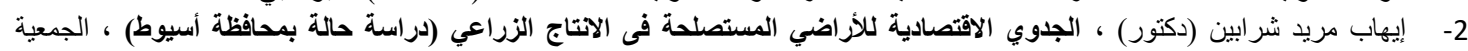

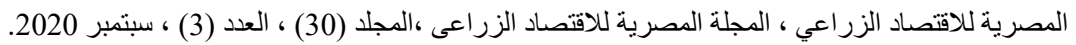

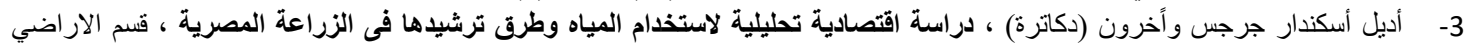

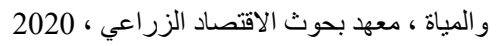

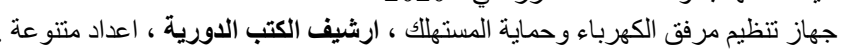

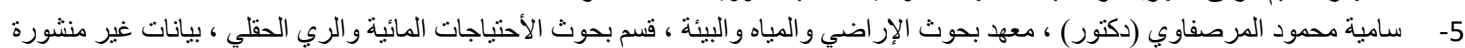

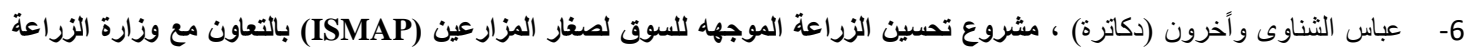

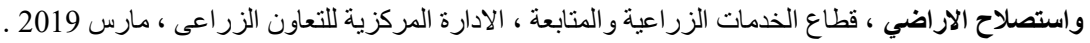

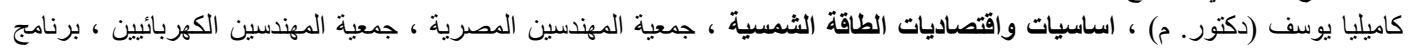

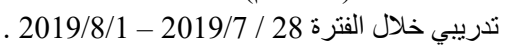

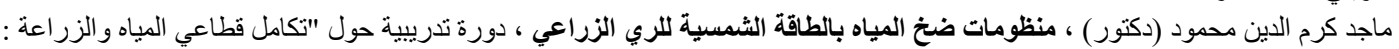

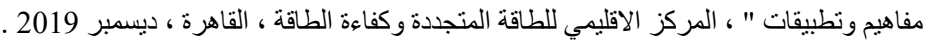
9- مصطفى منير (دكتور) ، أليات تفعيل تطبيقات أستخدام الطاقة الثمسية فى ايجاد تنمية حضرية مستدامة ، كلية التخطيط الاقليمي و العمر اني ، جامعة القاهرة . 10- وزارة الزراعة واستصلاح الأراضي ، مديرية الزراعة بأسيوط ، الادارة الزراعية لكل من مراكز الفتح ، ومنفلوط ، وديروط ، والبدارى ، قسم

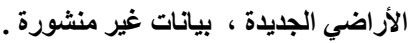

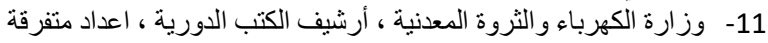

12- Maupoux M., (2010) "Soler (Photovoltaic) water pumping", practical ActionTechnology challerging poverty,of Green Empowerment, who has installed Soler water pumps in Nicaragua and Philippines

13- https://ar.wikipedia.org

14 -https://nasrsolar.com/wp-content/uploads/2018/06/lorentz.png

14- $\quad$ https://p.dw.com/p/2ocTo

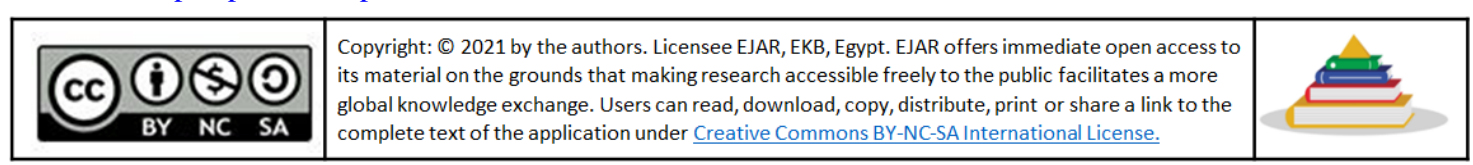




\title{
دراسة اقتصادية لاستخدام الطاقة الشمسية فى رى الإراضى الزراعية المستصلحة بمحافظة أسيوط المئس
}

\author{
د / إيهاب مريد شر ابين ميخائيل

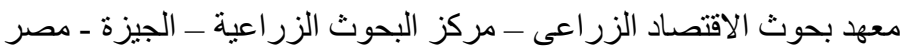 \\ الملخص العربي
}

الحصول على المياه فى مناطق استصلاح الاراضي الصحراوية فى جمهورية مصر العربية يعد من أكبر

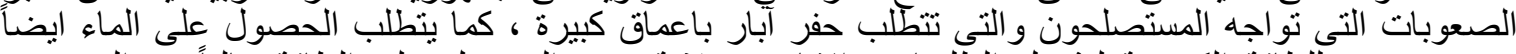

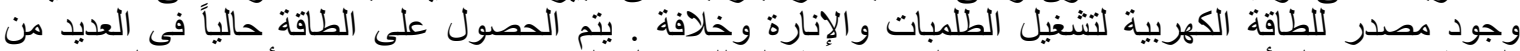

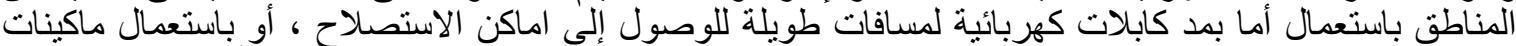

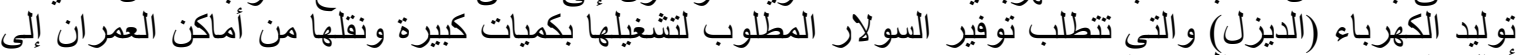

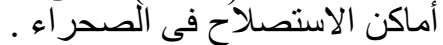
لوحظ فى الأونة الاخيرة أرتفاع تكاليف الري للإر اضي الزراعية المستصلحة التي تعنمد فى الحصول على الطاقة

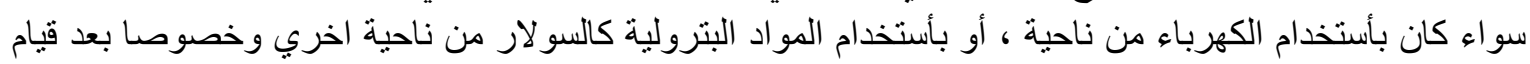

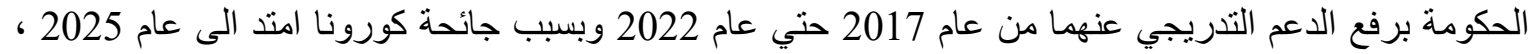

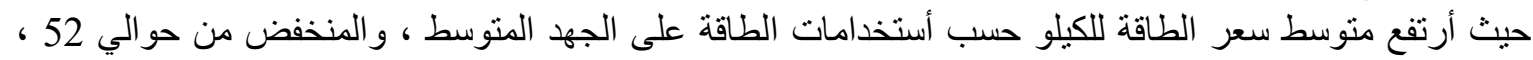

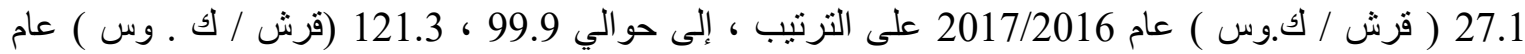

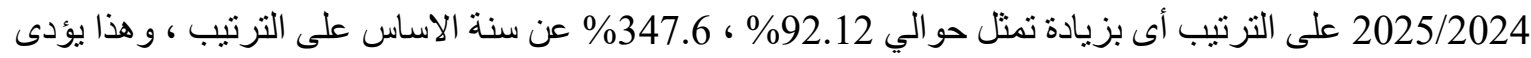

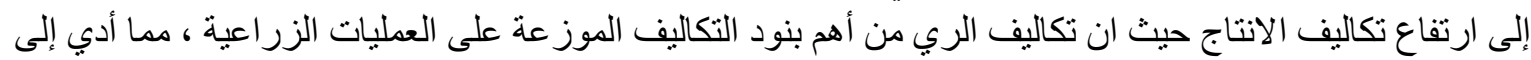

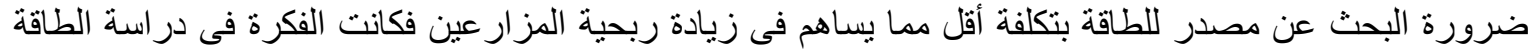

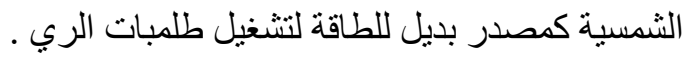

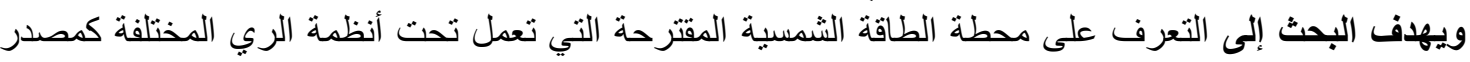

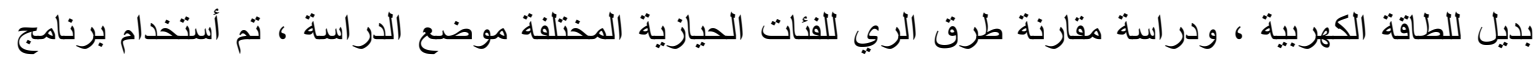

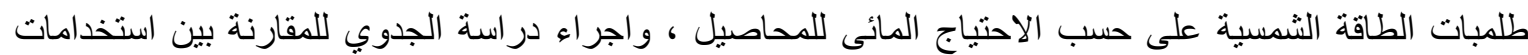

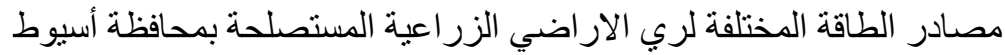

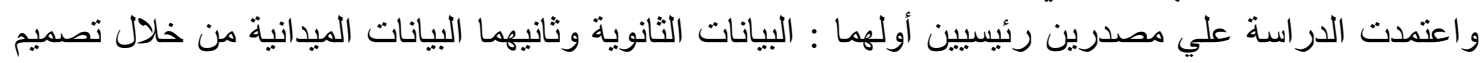

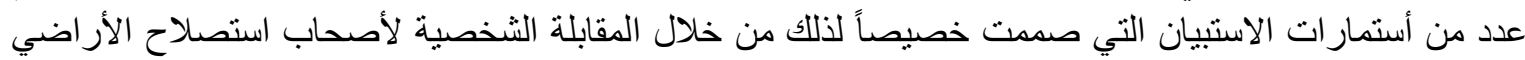

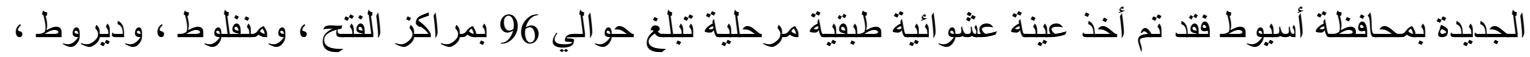

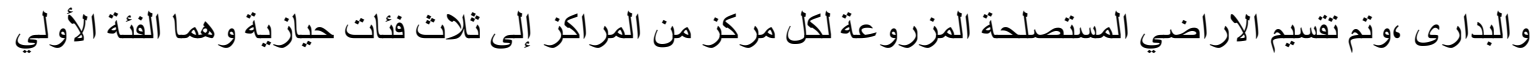

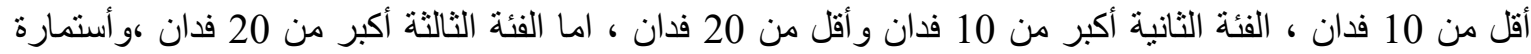

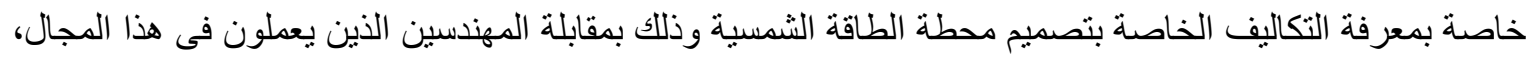

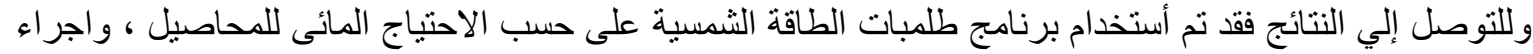

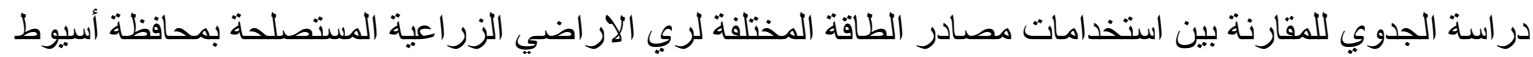

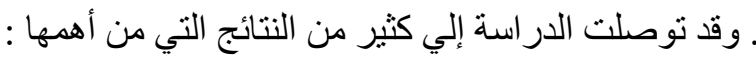

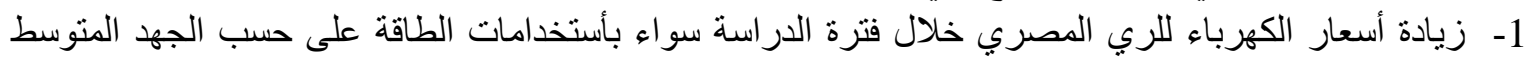

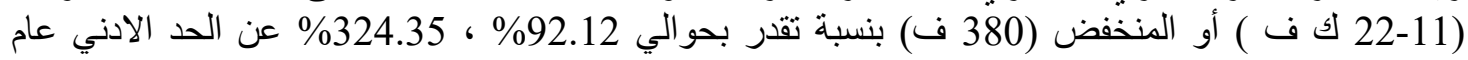

.(2017/2016)

2- الأحتباجات المائية اليومية للمحاصيل فى اليوم تختلف من مركز إلى اخر حسب نظم الري المختلفة المستخدمة

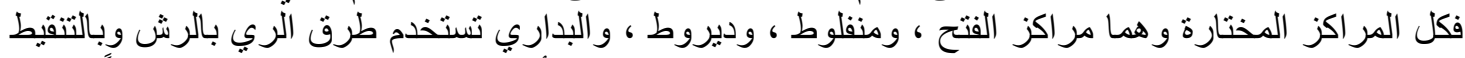

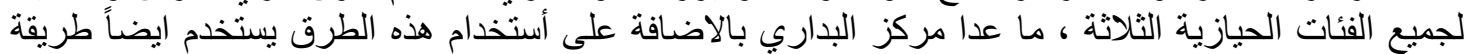

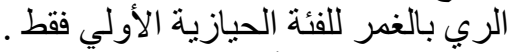
3- تبين من الدر اسة أن قدرة الطلمبة بالحصان غالبا ما تلكون مساوية لقدرة الالو الح الثمسية بالكيلووات لكل الفئات

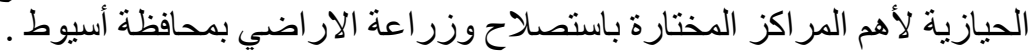

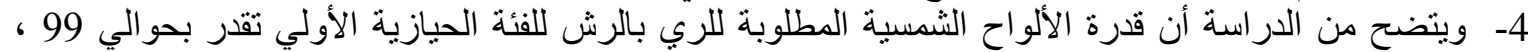

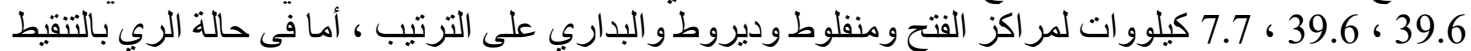

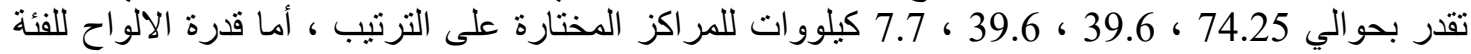

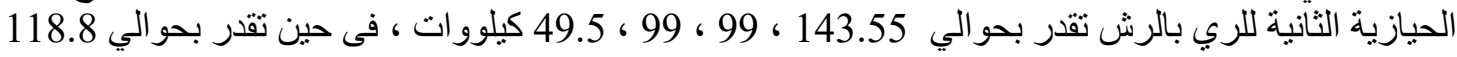


، 99 ، 74.25 ، 49.5 للري بالتنقيط للمر اكز المختارة على الترتيب ، كما يتبين ايضاً ان قدرة الالو اح الثمسية

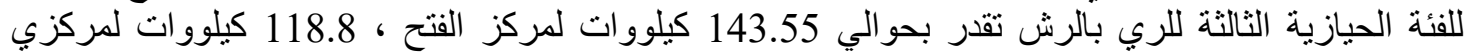

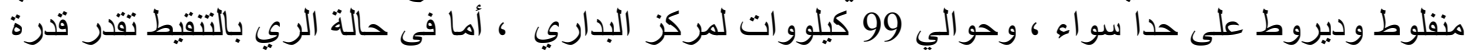

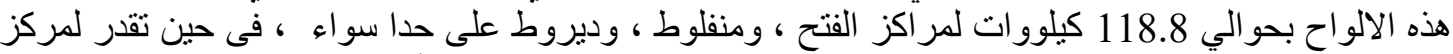

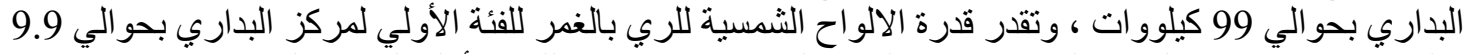

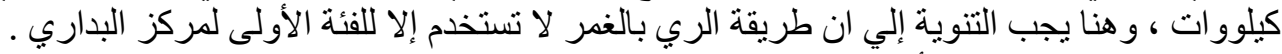

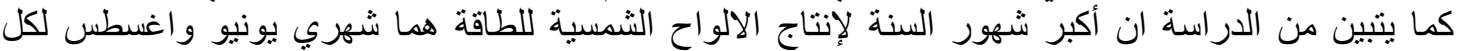

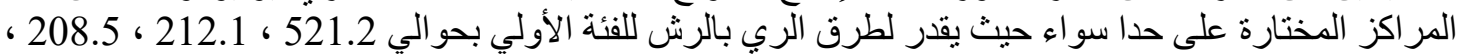

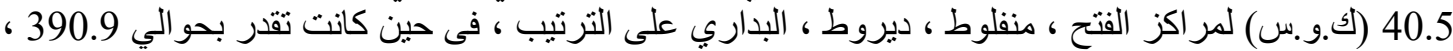

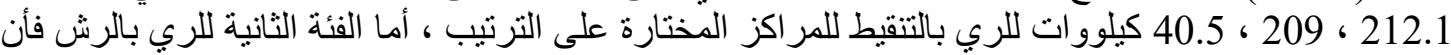

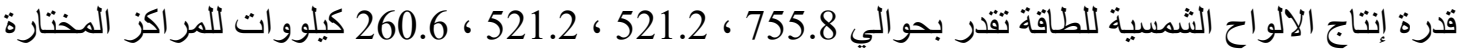

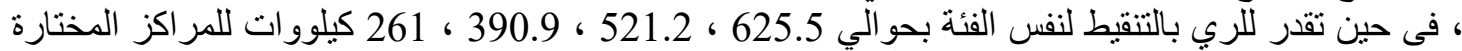

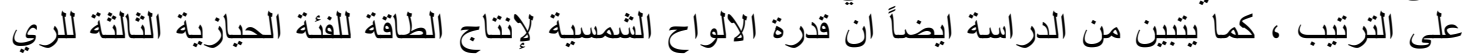

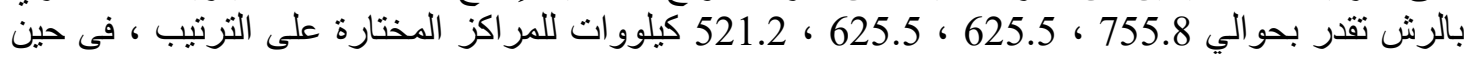

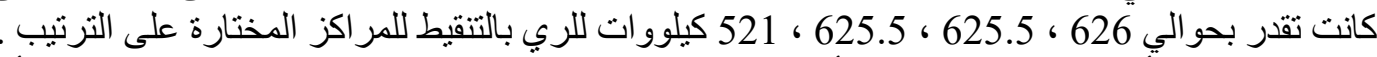

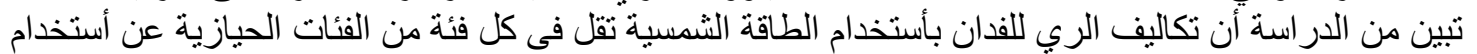

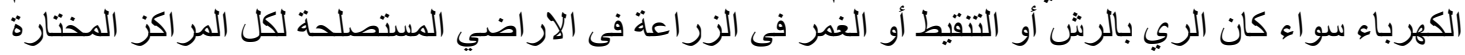

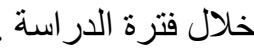

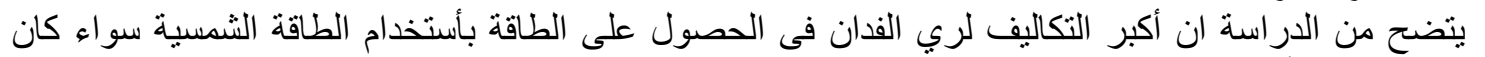

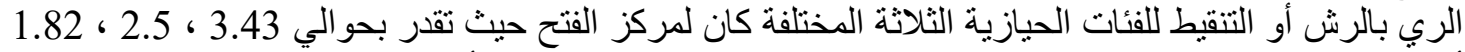

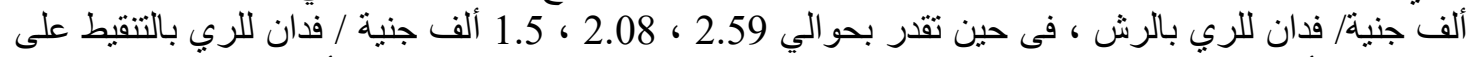

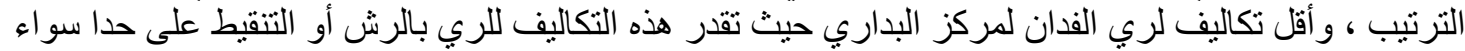

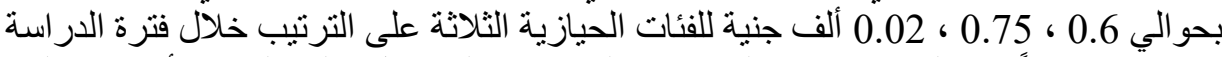

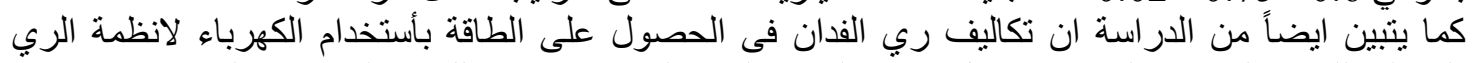

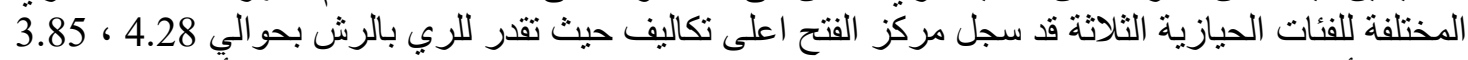

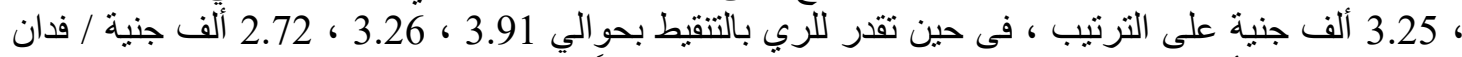

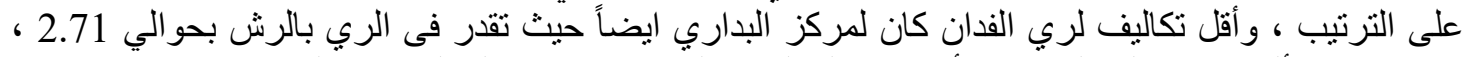

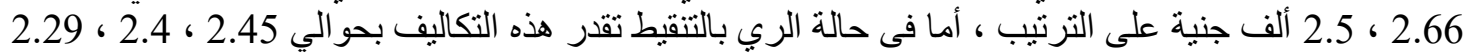

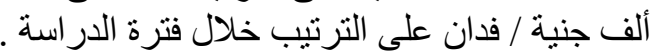

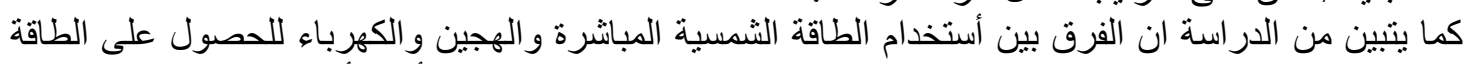

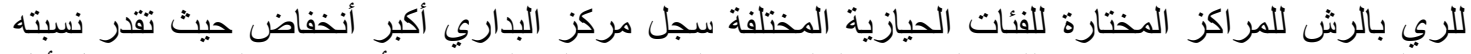

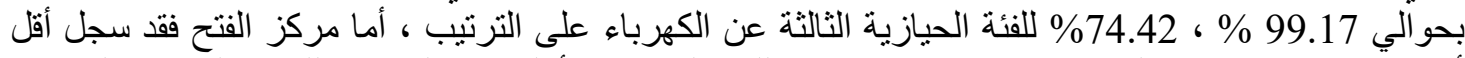

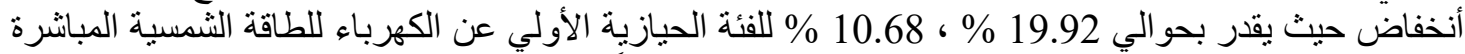

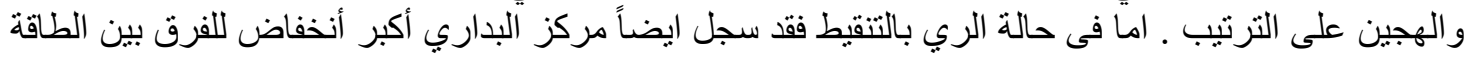

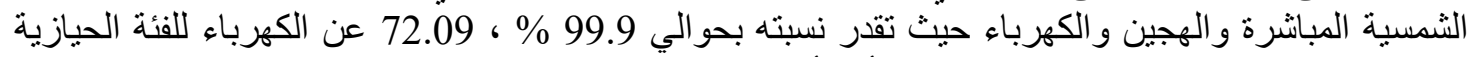

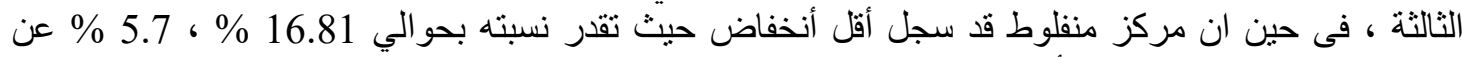

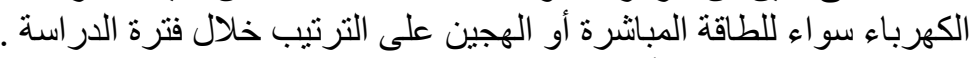

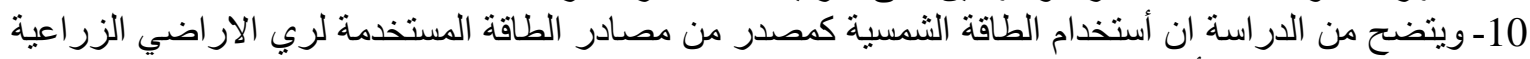

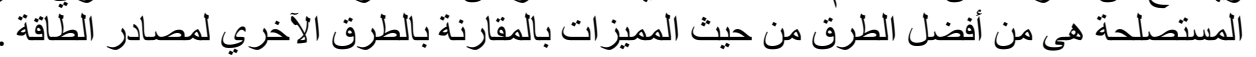
ومن أهم توصيات الدراسة :

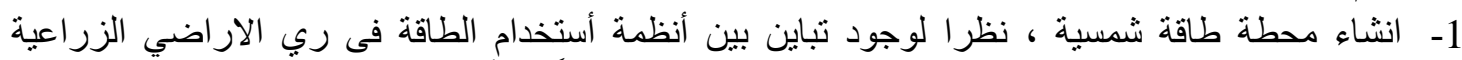

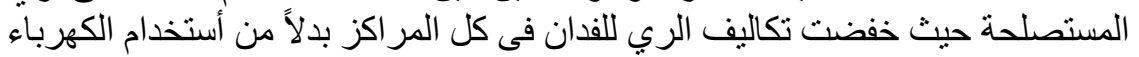

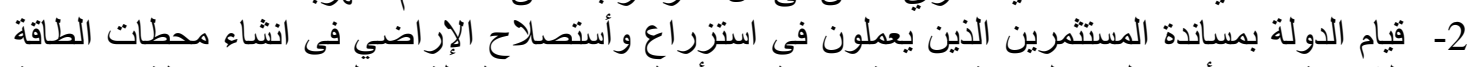

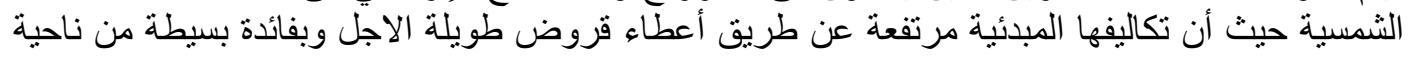

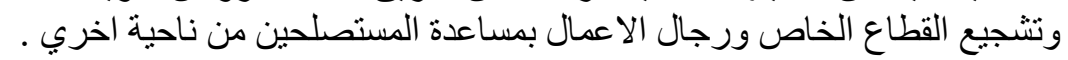

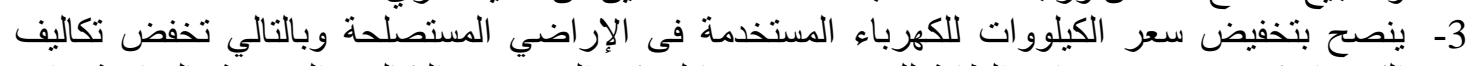

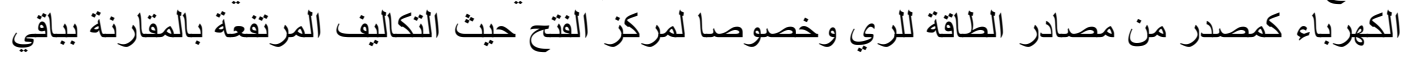

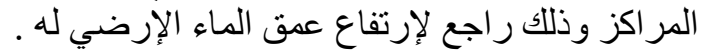

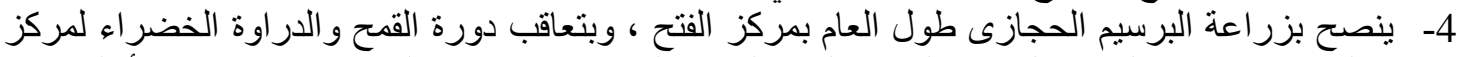

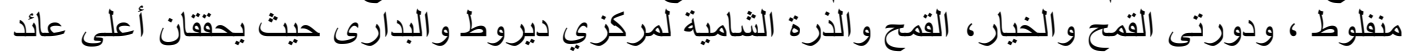

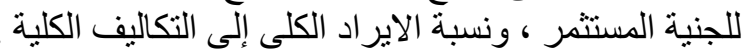


الملاحق :

جدول رقم (1): الاحتياجات المائية م3 / فدان لأهم المحاصيل المزروعة بالاراضي المستصلحة المزروعة بمناطق مصر العليا تحت أنظمة الرى المختلفة خلال متوسط الفترة ( 2017-2019).

\begin{tabular}{|c|c|c|c|c|c|c|}
\hline & \multicolumn{2}{|c|}{ الاحتياج اليومى م3/ فدان } & \multicolumn{3}{|c|}{ الاحتياجات المائية م3 / فدان } & \multirow[b]{2}{*}{ المحصول } \\
\hline الرى بالتنقيط & الرى بالرش & الرى بالغمر & الرى بالتنقيط & الرى بالرش & الرى بالغمر & \\
\hline & & & & & & المحاصيل الشتوية \\
\hline & 15 & 18 & & 2622 & 3278 & قمح \\
\hline & 21 & 26 & & 3803 & 4754 & برسيم مستديم \\
\hline 20 & 22 & 28 & 2947 & 3341 & 4176 & طماطم \\
\hline 16 & 18 & 23 & 2898 & 3285 & 4106 & باذنجان شتوى \\
\hline 14 & 16 & 20 & 2491 & 2824 & 3529 & بصل شتوى \\
\hline 17 & 19 & 24 & 3095 & 3508 & 4385 & بنجز \\
\hline 14 & 15 & 19 & 2038 & 2309 & 2887 & فول \\
\hline & & & & & & المحاصيل الصيفية \\
\hline 32 & 36 & 45 & 3649 & 4135 & 5169 & ذرة شامية \\
\hline 31 & 35 & 44 & 3547 & 4020 & 5025 & ذرة رفيعة \\
\hline 26 & 29 & 36 & 3074 & 3484 & 4355 & دراوة خضر اء \\
\hline 25 & 28 & 35 & 4419 & 5008 & 6265 & باذنجان صيفى \\
\hline 35 & 39 & 49 & 3808 & 4316 & 5396 & خيار \\
\hline 25 & 28 & 35 & 4484 & 5082 & 6352 & بصل صيفى \\
\hline 23 & 26 & 34 & 4308 & 4882 & 6103 & فلفل \\
\hline & 25 & 28 & & 9055 & 10344 & البرسيم الحجازى \\
\hline
\end{tabular}

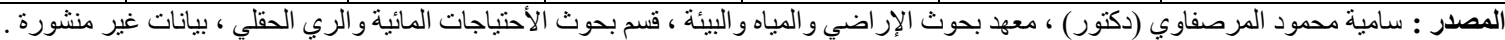

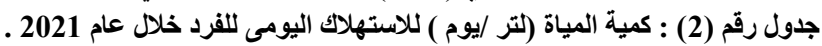

\begin{tabular}{|c|c|}
\hline كمية المياه المطلوبة (لتر/يوم) & الغرض من الاستخذام \\
\hline 6 & ل الشرب \\
\hline 4 & ل للطبخ \\
\hline 10 & ل ل استحمام \\
\hline 15 & صرف صحى \\
\hline 10 & غسيل الملابس \\
\hline 10 & غسيل الاو اني \\
\hline 5 & 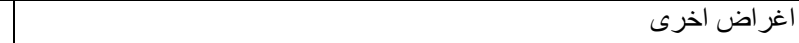 \\
\hline 60 & 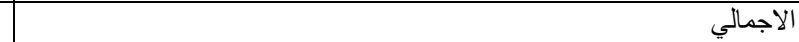 \\
\hline
\end{tabular}

https://nasrsolar.com/wp-content/uploads/2018/06/lorentz.png 